\title{
Introduced marine biota in Western Australian waters
}

\author{
John M. Huisman', Diana S. Jones ${ }^{2}$, Fred E. Wells ${ }^{3}$, and Timothy Burton ${ }^{2}$ \\ 'Western Australian Herbarium, Department of Fnvironment and Conservation, Locked Bag 104. \\ Bentley Delivery Centre, Western Australia 6983, Australia. \\ and School of Biological Sciences and Biotechnology, Murdoch University, \\ Murdoch, Western Australia 6150, Australia. \\ 2Department of Aquatic Zoology, Westem Australian Museum, Locked Bag 49, Welshpool DC, \\ Western Australia 6986, Australia. \\ ${ }^{3}$ Western Australian Department of Fisheries, Level 3, 168 St Georges Terrace, \\ Perth, Western Australia 6000, Australia.
}

\begin{abstract}
An annotated compendium is presented of 102 species of marine algae and animals that have been reported as introduced into Western Australian marine and estuarine waters, four of which are on the Australian national list of targeted marine pest species. For each species the authority, distribution (both in Western Australia and elsewhere), voucher specimen(s) and remarks are given. Sixty species are considered to have been introduced through human activity, including three on the list of Australian declared marine pests. The most invasive groups are: bryozoans (15 species), crustaceans (13 species) and molluses ( 9 species). Seven of these introduced species, including four natural introductions, have not been found recently and are not presently considered to be living in Western Australia. Twentysix species are regarded as cryptogenic or native. The records of nine species, including two declared marine pests, are questionable or rejected.

The distribution of the 60 introduced species shows that most (37) are temperate species that occur from Geraldton south; only 6 are tropical species that occur from Shark Bay north; 17 introduced species occur in both the southern and northern halves of Western Australia. Because most of the introduced species are temperate species, southern marine areas have more introduced marine species than northern areas. The greatest concentration is in the southwest comer: 46 in Fremantle, Cockburn Sound and the lower Swan River; 25 in Albany and 24 in Bunbury.

We conclude with a strong recommendation that continuing baseline taxonomic research and surveys of the Western Australian marine waters be regarded as an essential component of protecting and managing the State's valuable marine environment.
\end{abstract}

\section{INTRODUCTION}

The introduction of exotic species into the marine environment is a major threat to native biodiversity and ecosystem health (Padilla et al. 1996; Hass and Jones 2000). Three primary vectors for marine introductions are recognised - via ballast water discharge, hull fouling or deliberate introductions, such as through aquaculture (Carlton 1985) (species can also be accidentally introduced by being attached to deliberately introduced organisms such as oysters). While most introductions remain relatively passive and apparently co-exist with native species without detriment, many others have the ability to become pests, dominating and excluding local species and resulting in major shifts in ecosystem structure (Brenchley and Carlton 1983; Grosholz and Ruiz 1995). Local loss of biodiversity is an inevitable result of these pest intrusions (Paesanti et al. 1991; Blanchard 1995; Blanchard 1997; Wyatt et al. 2005). Some introduced species can directly impact human health, for example by toxin accumulation in shellfish due to toxic dinoflagellates (Hallegraeff et al. 1988). Consumption of contaminated shellfish may result in illness or death (Campbell 1994; Walters 1996).

Western Australia (WA) has, thus far, remained relatively free of marine pests. Jones (1992a) recorded 25 marine introductions into the State's waters, over half (15) detected since the 1970s and most of those introduced by shipping, either as fouling organisms or via ballast water. Furlani (1996) also recorded 25 introduced marine species in Western Australia. In 1999, this number was increased to 30 (Hass and Jones 1999). Those introductions that have been reported have 
generally remained innocuous, or have been largely restricted to artificial environments such as harbours. This parallels the situation in other Australian areas. A search of the National Introduced Marine Pest Information System website (NIMPIS 2002) reveals a list of 44 species introduced or possibly introduced into WA. Additional information presented here increases the number of known introduced species to 60 . As yet there are no published data regarding adverse impacts of introduced species in Western Australia (Hass and Jones 1999), but several have been shown to have significant impacts in other areas, by competition for food and/or space. For example, no threats to Western Australian native species, fisheries or seagrass beds were identified through the introduction of Sabella spallanzanii, the European fan worm (Clapin and Evans 1995), although studies in Victoria have suggested that this species has the potential to compete with native filter feeders and change the structure of the benthic food web (Walters 1996). Adverse impacts may not occur until decades after the initial introduction and establishment (Courtney 1990) and it would, therefore, be extremely short-sighted to assume that Western Australia's relatively unaffected marine environment is somehow immune to infestation by pest species

While the impact of introduced species in WA is as yet unknown, the likelihood of a pest outbreak is high, as the State includes many high traffic ports with a variety of habitats, ranging from tropical to temperate. Even a cursory review of the marine species known to be pests elsewhere will reveal that, for most, suitable conditions for their growth and possible survival can be found somewhere in the State (Department of Agriculture, Fisheries and Forestry 2006). Thus the risk of a pest incursion is high and on-going vigilance is important if WA is to remain relatively pest free. It is also pertinent to point out here that the incursion of marine pests is a two-way process. For example, the Australasian barnacle Austrominius modestus Darwin was introduced into Europe from Australia or New Zealand following the end of World War II, attached to the hulls of returning ships (Bishop, 1947). The species spread, becoming established on the British mainland coast and then extending to Europe (Bishop and Crisp 1957; Crisp 1958). Currently the species occurs from the Shetland Islands to Portugal and Maderia (Southward and Crisp 1963; Hiscock et al. 1978; O'Riordan and Ramsay 1999; Wirtz et al. 2006). Similarly the temperate Australian gastropod Bedeva paivae (Crosse, 1864) has colonised South Africa (Kilburn and Rippey 1982) and the south-western Australian green alga Caulerpa racemosa var. cylindracea (Sonder) Verlaque, Huisman and Boudouresque has become a major pest in the Mediterranean (Verlaque et al. 2003). The vector by which these introductions occurred is not known, especially in areas where native fauna is not well documented.

Several factors can hamper marine pest surveys. Obvious impediments include the marine environment itself, as most introductions remain hidden from sight, their presence often only revealed by snorkelling or SCUBA diving. Perhaps of greater significance, however, is the difficulty in accurately identifying introduced species and assessing their impact. For almost all introduced species it is virtually impossible to ascertain the 'event' that led to the introduction, and many are not observed until they are well established and essentially impossible to eradicate. Accurate identification is essential, primarily to ensure that introduced species are not missed, but equally to ensure that native species are not inadvertently recorded as introductions, as there are many undescribed native species. For example, some species generally considered to be cosmopolitan may be undocumented introductions or, conversely, non-introduced native species (Chapman and Carlton 1991; Poore 1996).

The large number of ships, private yachts, and illegal foreign fishers means that there is a considerable current potential for additional marine species to be introduced into WA. The current resource boom is concentrated in the Pilbara, but includes all parts of Western Australia. The planned increase in shipping movements means there will be increased threats of species being introduced into WA. There have already been several incidents that give cause for alarm. In October 2002, the cutter suction dredge Leonardo da Vinci arrived in Geraldton almost directly from the Caribbean and had a number of foreign species, including potential pest species, in its sea chests or attached to its hull. Prompt action was taken by authorities to minimise the chances of an introduction. A resurvey is planned to see if any species have been introduced. A second incident occurred in late 2006, when the dredge Volvox Australia arrived at the port of Dampier fouled with the Asian green mussel, Perna viridis. It was denied entry and went to Singapore for cleaning in drydock before being allowed to return to WA. More recently a barge arrived in Dampier and on inspection was found to have an extensively fouled hull. It was immediately ordered to go out to the $200 \mathrm{~m}$ depth contour and be cleaned before returning to port; on return to the coast the ship was reinspected and allowed to enter Port Hedland.

In managing incidents such as these, it is critical that we understand what species have been introduced into Western Australia and where they occur. This paper develops the required information. 


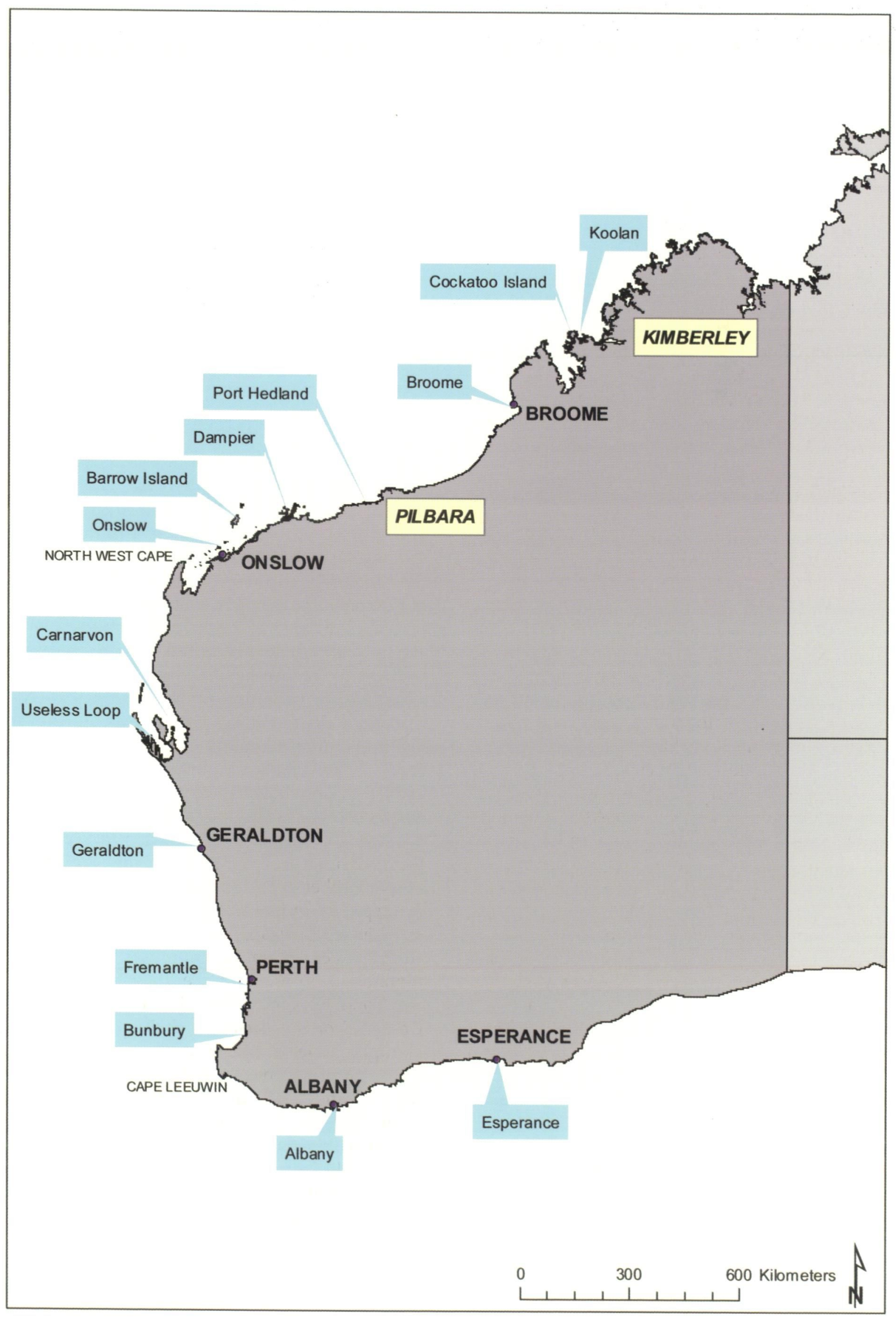

Figure 1 Map of the major areas of Western Australia where introduced marine species have been reported. 


\section{MATERIALS AND METHODS}

This paper presents a list of species reported or believed to have been introduced into Western Australian waters. The records have been drawn from a variety of sources, including the scientific literature, several unpublished surveys of WA ports and unpublished information. Figure 1 shows the major marine areas in Western Australia where introduced species have been recorded. Table 1 shows the major surveys of Western Australian ports. We have listed all species previously documented as 'introduced' in the State. In addition, several species included herein are newly recorded; these meet at least some of the criteria used by Chapman and Carlton (1994, see below) for recognition of introduced species. Cryptogenic species (i.e., those potentially introduced but their origins presently obscure due to their widespread distribution) are listed only if they are known to exhibit pest tendencies elsewhere.

Listed for each species are the authority and distribution (both Western Australian and elsewhere) incorporating published records and whether there are voucher specimen(s) in the WA Museum, WA Herbarium or other institutions. Occasionally no vouchers were available to support the records and these species should be viewed critically. Where several works are cited, it is likely that the earliest published will represent the original record, with those following generally not providing new records but repeating the original. A remarks section includes an assessment of any questionable records and an evaluation of the pest potential of the species. Finally, several tables indicating the present status of the species are given.

Abbreviations for voucher specimens are: $\mathrm{WAM}=$ Western Australian Museum; PERTH $=$ Western Australian Herbarium; $\mathrm{AD}=$ Adelaide Herbarium; MUCV $=$ Monash University Botany Department Herbarium; $Q M=$ Queensland Museum; $A M=$ Australian Museum; MV = Museum of Victoria.

\section{Assessing native or introduced status}

Several species listed herein represent new (or recent) records for Western Australia. These may simply have been overlooked previously, but their proximity to harbours suggests potential introductions. They have been assessed against the list of criteria provided by Chapman and Carlton (1994) to objectively identify marine introductions, including:

1. Previously unknown locally (herein interpreted as no published records and no specimens in the WA Museum or Herbarium)

2. Post introduction range extension

3. Human mechanism of introduction

4. Association with known introductions

5. Association with artificial or altered environments

6. Discontinuous or restricted regional distribution

7. Disjunct global distribution

8. Insufficient life history adaptations for global dispersal

9. Exotic evolutionary origin

These criteria are particularly useful when assessing recent introductions, but the status of species introduced some time ago and since naturalized cannot be determined without additional study, typically involving DNA sequencing methods to assess relationships between the local population and potential source populations. Voucher collections in museums and herbaria can also assist in determining a species' status, but these are often not available and historically record-keeping was generally not as detailed or consistent as it presently is. Compounding these difficulties is the high likelihood that populations of many widespread species arose from multiple introductions over time. In such cases, when a species is known to be widely distributed but its origin (or native range) cannot be determined, the species is regarded as 'cryptogenic'. A cryptogenic species may or may not be introduced, but current methods do not allow a definitive assessment. A species that is cryptogenic in one location, however, may subsequently be introduced to another.

\section{DISCUSSION}

A total of 102 species are discussed in the present paper, enabling a more accurate assessment of the status of introduced marine species in Western

Table 1 Major surveys for introduced marine species in Western Australia.

\begin{tabular}{lll}
\hline Location & Reference & Identifications \\
\hline Esperance & Campbell (2003b) & WA Museum \\
Albany & CRIMP (1997b) & CRIMP \\
Bunbury & CRIMP (1997a) & CRIMP \\
Fremantle & CRIMP (2000) & Various; WA Museum identified vouchers \\
Geraldton & Campbell (2003a) & WA Museum \\
Dampier & Wells et al. (2003); Jones (2004) & WA Museum surveys accepted by NIMCPG in lieu of broad \\
& CRIMP (1999) & Survey; numerous specialists identified the material. \\
Port Hedland & CRIMP
\end{tabular}


Table 2 Targeted pest species in Western Australia (4 spp.)

Dinoflagellates

Alexandrium minutum

Alexandrium tamarense ${ }^{1}$

Polychaetes

Sabella spallanzanii

Molluscs

Musculista senhousia

${ }^{1}$ Requires confirmation by genetic studies.

Australia. Only four species are on the Australian national list of targeted marine pest species (Table 2). Two are dinoflagellates, Alexandrium tamarense and $A$. minutum, although the record of $A$. tamarense is yet to be positively confirmed by genetic analyses (Hallegraeff 2007; pers. comm.). The other targeted marine pest species are the polychaetes Sabella spallanzanii and the bivalve mollusc Musculista senhousia. Table 3 lists 60 marine species that have been introduced and and are presently established in Western Australia. They represent a wide range of plant and animal taxa. The groups with the most introduced species are bryozoans (15), crustaceans (13) and molluscs (9). Seven species have been reliably reported as introduced to Western Australia (i.e., with vouchers) but have not been collected or observed recently and are not presently known to occur in the State (Table 4). Four of these are natural introductions (Macpherson 1953; Wells and Kilburn 1986). Twenty-six species are considered to be cryptogenic or native (Table 5). The records of nine species are questionable or have been excluded (Table 6).

Altogether, 60 species are classified as being introduced and currently living in Western

Table 3 Marine species introduced and presently established in Western Australia (60 spp.)

Dinoflagellates ( $1 \mathrm{sp}$.

Alexandrium minutum

Algae (4 spp.)

Elachista orbicularis

Grateloupia imbricata

Pseudocodium de-vriesii

Stictyosiphon soriferus

Bryozoans (15 spp.)

Amathia distans

Amathia vidovici

Bowerbankia gracilis

Bugula flabellata

Bugula neritina

Bugula stolonifera

Conopeum seurati

Cryptosula pallasiana

Savignyella lafontii

Schizoporella errata

Schizoporella unicornis

Tricellaria occidentalis

Watersipora arcuata

Watersipora subtorquata

Zoobotryon verticillatum

Crustaceans (13 spp.)

Amphibalanus amphitrite

Amphibalanus reticulatus

Cirolana harfordi

Paracerceis sculpta

Paradella dianae

Sphaeroma serratum

Megabalanus ajax

Megabalanus rosa

Megabalanus tintinnabulum

Monocorophium acherusicum

Monocorophium insidiosum

Monocorophium sextonae

Tesseropora rosea
Hydroids (6 spp.)

Antennella secundaria ${ }^{2}$

Ectopleura crocea

Eudendrum carneum

Halecium delicatulum

Obelia dichotoma

Sarsia eximia

Molluscs (9 spp.)

Velacumantus australis

Godiva quadricolor

Musculista senhousia

Mytilus edulis planulatus

Okenia pellucida

Ostrea edulis

Polycera hedgpethi

Scaeochlamys livida

Theora lubrica

Polychaetes (4 spp.)

Alitta succinea

Boccardia proboscidea

Ficopomatus enigmatica

Sabella spallanzanii

Ascidians (5 spp.)

Ascidiella aspersa

Botryllus schlosseri

Ciona intestinalis

Styela clava

Styela plicata

Fish (3 spp.)

Acentrogobius pflaumi

Sparidentex hasta

Tridentiger trigonocephalus

${ }^{2}$ considered by NIMPIS (2002) to be cryptogenic in parts of WA but introduced to the Pilbara region. 
Table 4 Marine species introduced but not presently found in Western Australia (7 spp.)

\section{Crustaceans}

Carcinus maenas

Pyromaia tuberculata

\section{Molluscs}

Bullia annulata (natural introduction)

Crassostrea gigas

Cymatium cutaceum africanum (natural introduction)

Haliotis spadicea (natural introduction)

Nassarius kraussianus (natural introduction)

Table 5 Species considered to be cryptogenic or native (26 spp.)

Dinoflagellates

Alexandrium tamarense ${ }^{3}$

\section{Algae}

Acarithophora spicifera

Acrosymphyton taylorii

Caulerpa taxifolia

Cottoniella fusiformis

Endarachne binghamiae

Eucheuma denticulatum

Hypnea musciformis

Ulva fasciata

Ulva taeniata

\section{Bryozoans}

Aetea anguina

Beania mirabilis

Synnotum aegyptiacum

Tricellaria inopinata

\section{Hydroids}

Aglaophenia parvula

Antennella secundaria ${ }^{4}$

Eudendrium capillare

Gymnangium gracilicaule

Obelia bispinosa

Obelia longissima ${ }^{5}$

Plumularia setacea

Plumularia warreni

\section{Molluscs}

Nassarius burchardi

Spisula trigonella

Polychaetes

Hydroides elegans ${ }^{6}$

\section{Ascidians}

Botrylloides leachi

\footnotetext{
3 Requires confirmation by genetic studies.

4 considered by NIMPIS (2002) to be cryptogenic in parts of WA but introduced to the Pilbara region.

${ }^{5}$ according to sections of NIMPIS (2002), this species is not recorded from Australia, but elsewhere on the site is listed as cryptogenic

${ }^{6}$ Regarded as a possible introduction by NIMPIS (2002).
}

Table 6 Questionable and excluded records (9 spp.)

Dinoflagellates

Alexandrium catenella

Gymnodinium catenatum

Algae

Striaria attenuata

Crustaceans

Amphibalanus improvisus

Molluscs

Haliotis diversicolor

Haliotis hargravesi

Teredo navilis

Polychaetes

Polydora ciliata

Pseudopolydora paucibranchiata

Australia. All of these species occur in marine areas associated with harbours. A majority (34 species) have been recorded only in harbours. Twenty-six species occur both in harbours and on nearby open coasts, including estuaries such as the mouth of Peel Inlet. This strongly suggests species are being introduced through major nodes of human activity, followed by some spread to nearby areas. However, it should be noted that surveys for introduced species have been concentrated in harbours and the records from adjacent open shores are incidental. A targeted survey would be required to determine how widespread introduced species have become outside harbours. The most diverse groups on open coasts are bryozoans ( 7 species) and barnacles (5 species). The bryozoans were all recorded in Shark Bay by Wyatt et al. (2005), and the barnacles from the various papers of DSJ.

A second major finding of Table 7 is that most of the marine species introduced into Western Australia are cooler water, temperate species (37 species) that occur from Geraldton south; only 6 are tropical species that occur from Shark Bay north; 17 introduced species occur in both the southern and northern halves of Western Australia. The preponderance of temperate species is in agreement with most published work on introduced species. It must be noted that the Port of Dampier, which has considerable shipping activity, has not been surveyed in detail, although the associated Dampier Archipelago, which includes a broad variety of marine habitats, has been the subject of several intensive marine biodiversity surveys (Wells and Walker 2003; Jones 2004a). Because most of the introduced species are temperate, it follows that southern marine areas have more introduced marine species than northern areas. The greatest concentration is in the southwest corner of Western Australia: Fremantle (including Cockburn Sound and the lower Swan River) has 46 introduced 
species and is the port with the largest number of vessel movements. Albany (25), Bunbury (24) and Esperance (15) are all smaller ports with fewer vessel movements and fewer introduced marine species. In addition to the high vessel activity in the Fremantle marine area, there is also considerable habitat diversity (both natural and artificial), which provides a variety of niches for introduced species to occupy. In this regard, the Albany area also has a wide variety of habitats in close proximity (Wells 1990), so the large number of introduced species might be expected. Esperance has a much lower habitat diversity (Kendrick et al. 2005), so fewer species would be expected in that area. Bunbury stands out in this regard. The marine area is small and habitat diversity is low, so it would be expected to have relatively few introduced species. Instead, at 24, the number of introductions is high. A separate analysis is currently being undertaken of the numbers of vessel movements and where the vessels have come from.

It is impossible to know when most of the species were introduced into Western Australia. Lamarck (1819) described Mytilus edulis planulatus from King George Sound. If the species is in fact introduced as we believe, it arrived with the very first European boats to visit the south coast and eastern Australia. That $M$. edulis is introduced has already been suggested by Hewitt (2003). Morton et al. (2003) reported the European oyster Ostrea edulis (Linnaeus, 1758) from Oyster Harbour, Albany. This species was also probably an early arrival. The first record of an introduced species in Western Australia appears to be the barnacle Amphibalanus amphitrite (Darwin, 1854), which was recorded from Broome, north-western Australia by the Swedish Mjöberg Expedition (1910-1913; in Broch 1916), although it was known previously from the east coast (Darwin 1854). Subsequently, the ascidian Botryllus schlosseri (Pallas, 1766) was recorded by Hartmeyer and Michaelsen (1928). These were followed by the polychaetes Alitta succinea (Leuckart, 1847) and Ficopomatus enigmatica (Fauvel, 1923) by Monro (1938). Kott (1952) reported the ascidian Styela plicata (Lesueur, 1823). There were two species recorded in the late 1970 s and 11 in the 1980s. The great majority were reported in the 1990s and earlier this decade, many as a result of surveys undertaken by the CSIRO's Centre for Research on Introduced Marine Pests (CRIMP) and other surveys. However, many of these species may have been in Western Australia well before the first literature record. For example, the polychaete Sabella spalanzanii was first reported by Clapin and Evans (1995). Subsequent examination of the WA Museum collections demonstrated that the first specimen was collected in Albany in 1965 but it was not identified at that time.
The NIMPIS (2002) database can be searched by state or territory. A search of the database for introduced species lists the following numbers: Victoria (57); New South Wales (55); Tasmania (45); Western Australia (44); South Australia (43); Queensland (26); and the Northern Territory (9). While the data are out of date, identifications were often not done by specialists in the various groups, and are not backed by voucher specimens, they do suggest that on a nationwide basis there tend to be more introduced marine species on the temperate south coast than in the tropical northern waters, a point discussed by Hutchings et al. (2002). With about a third of Australia's coastline, Western Australia ranks fourth of the six states in the number of introduced marine species, just one species ahead of South Australia. We recognise 60 species as being introduced and 26 as cryptogenic in the entire state of Western Australia. Hewitt et al. (2004) report 99 species as introduced to Port Phillip Bay, Victoria, alone, and an additional 61 cryptogenic species in the bay. However, it should be recognised that the number of known introduced species is probably inflated by the detailed studies that have been conducted. There is cause for comfort in the relatively low number of species introduced into Western Australia given the $14,000 \mathrm{~km}$ of coastline and wide range of temperatures, spanning the full range of tropical and temperate habitats. However, it should be remembered that there have been recent incursions of the black striped mussel Mytilopsis sallei on illegal Indonesian fishing boats in Broome and Port Hedland and the Asian green mussel Perna viridis into Dampier. Whatever the current situation, there is still a great need for continued vigilance.

One aspect arising from this project, for which we have co-opted the term "the taxonomic impediment" (Taylor 1983), warrants further comment. It is recognized that the identification of introduced species is a difficult process that requires specialist taxonomic knowledge and historic faunistic and floristic data (Hass and Jones 2000). A common thread running through much of the literature regarding marine introductions is the lack of baseline studies and the difficulty in accurately identifying specimens. For example, the CRIMP survey of Fremantle Port (CRIMP 2000) recorded 44 species of red algae (Rhodophyta), of which 28 were essentially unidentified (Red sp. 1, etc.) and a further four are identified to genus only. Granted the study was targeted primarily at introduced and pest species, but how then does one recognise new introductions if the biota is not identified? A consequence of this inability to identify the vast majority of species is that the survey has no value as a baseline for further work. Also, if a species is not identified, there is no basis for knowing whether or not it is introduced. If 
Table 7 Distribution of introduced marine species in Western Australia. (Note: Fremantle includes Cottesloe, Cockburn Sound, Garden I., Swan R. and Rockingham)

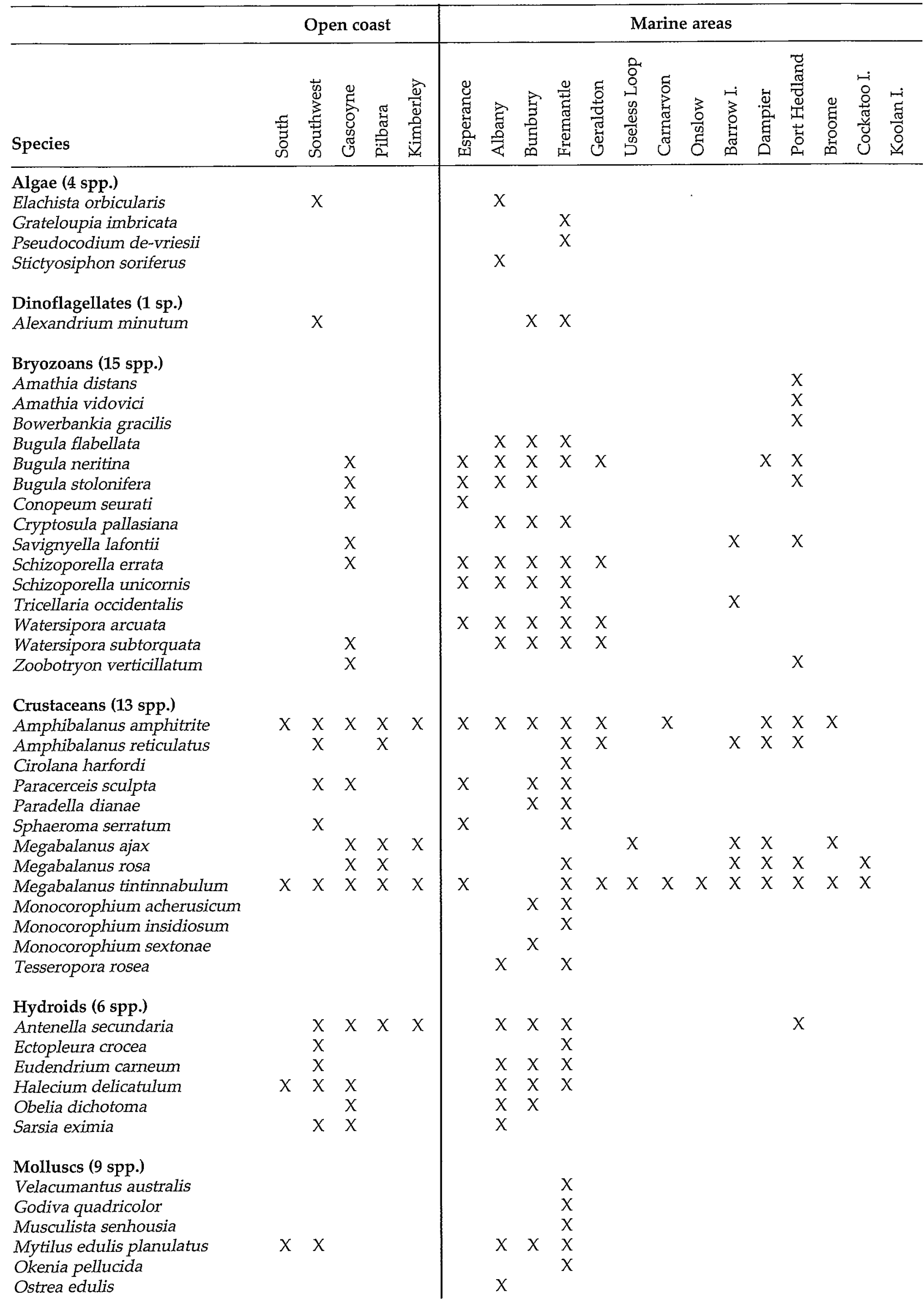


Table 7 (cont.)

\begin{tabular}{|c|c|c|c|c|c|c|c|c|c|c|c|c|c|c|c|c|c|c|c|}
\hline & & Op & en cc & ast & & & & & & & & $\operatorname{arin}$ & are & & & & & & \\
\hline Species & 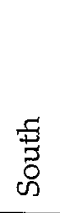 & 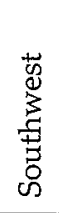 & 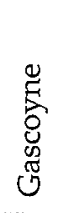 & $\underset{\tilde{\pi}}{\stackrel{\pi}{\approx}}$ & 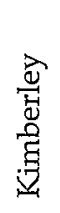 & 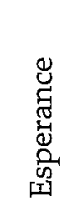 & $\begin{array}{l}\text { 怘 } \\
\text { 坖 }\end{array}$ & 急 & 怨 & $\begin{array}{l}\frac{5}{0} \\
\frac{+}{0} \\
\frac{3}{4} \\
0\end{array}$ & 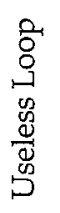 & 点 & $\begin{array}{l}3 \\
0 \\
0 \\
0 \\
0\end{array}$ & 位 & 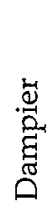 & 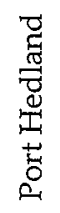 & 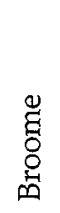 & 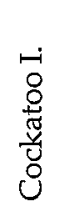 & 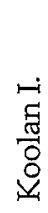 \\
\hline $\begin{array}{l}\text { Polycera hedgpethi } \\
\text { Scaeochlamys livida } \\
\text { Theora lubrica }\end{array}$ & & & & & & & $x$ & & $\begin{array}{l}x \\
X \\
X\end{array}$ & & & & & & & & & & \\
\hline $\begin{array}{l}\text { Polychaetes (4 spp.) } \\
\text { Alitta succinea } \\
\text { Boccardia proboscidea } \\
\text { Ficopomatus enigmatica } \\
\text { Sabella spallanzanii }\end{array}$ & & $x$ & & & & $X$ & $X$ & $X$ & $\begin{array}{l}X \\
X \\
X \\
X\end{array}$ & & & & & & & & & & \\
\hline $\begin{array}{l}\text { Ascidians (5 spp.) } \\
\text { Ascidiella aspersa } \\
\text { Botryllus schlosseri } \\
\text { Ciona intestinalis } \\
\text { Styela plicata } \\
\text { Styela clava }\end{array}$ & & & $\begin{array}{l}x \\
x\end{array}$ & $\begin{array}{l}X \\
x\end{array}$ & & $\begin{array}{l}X \\
X \\
X \\
X\end{array}$ & $\begin{array}{l}X \\
X \\
X \\
X\end{array}$ & $\begin{array}{l}X \\
X \\
X\end{array}$ & $\begin{array}{l}X \\
X \\
X \\
X \\
X\end{array}$ & & & & & & & & & & \\
\hline $\begin{array}{l}\text { Fish ( } 3 \text { spp.) } \\
\text { Acentrogobius pflaumii } \\
\text { Sparidentex hasta } \\
\text { Tridentiger trigonocephalus }\end{array}$ & & & & & & & & $x$ & $\begin{array}{l}X \\
X \\
X\end{array}$ & & & & & & & & & & \\
\hline Totals (60 spp.) & 4 & 14 & 18 & 8 & 4 & 15 & 25 & 24 & 46 & 7 & 2 & 2 & 1 & 6 & 6 & 12 & 3 & 2 & 0 \\
\hline
\end{tabular}

voucher specimens are deposited in the State Museum or Herbarium, future studies by taxonomists are possible, but unfortunately specimen deposition has often been neglected.

In the past, a number of surveys of Australian ports have been conducted. The specimens collected were treated in different ways by a variety of contractors who conducted the work, often without the aid of taxonomists. Few collections were deposited in Australian museums or herbaria, so recorded distributions could not be verified by vouchered specimens. As part of the National System for the Prevention and Management of Introduced Marine Pests in Australia, funding was provided by the Natural Heritage Trust for the Port Survey Integration project (2005-2006), to firstly trace these collections and secondly relocate them to the relevant state museums and herbaria, where they could be housed, curated and made available for scientific study. Very few vouchers had been kept of marine algae. For fauna, 50,735 specimen lots were retrieved and deposited, including 15,967 in the Western Australian Museum. The material ranged from unsorted lots in varying states of preservation to material identified to species. Specimens representative of introduced marine faunal pest, introduced and cryptogenic (likely introduced) species, which had been identified in each surveyed port, were verified by state museums dependent on the taxonomic expertise available. Fifteen introduced species and 17 cryptogenics were identified from the Western Australian material. These records are accessible nationally via the OZCAM website (Online Zoological Collections of Australian Museums). It is interesting to note that only one specific taxonomic group, the barnacles, had all the specimens identified to species in every port collection by a taxonomic expert (DSJ, an author of the present paper). Although this makes the barnacle data set a potent national asset, it also emphasises the severe lack of taxonomic expertise in Australia and the problems facing us in the identification of introduced pests, which in the port surveys were often identified by contractors with varying skill levels.

A more positive example is the marine biological survey of the waters of the Dampier Archipelago conducted by the WA Museum from 1998 to 2002 (Jones 2004a). Although this survey excluded the Port of Dampier, five species of introduced barnacles were recorded in the area, including port areas (Jones 2004b). Overall $>4500$ marine animal and plant species collected by the survey were identified to species by expert taxonomists worldwide, vouchered and deposited in the collections of the Western Australian Museum and the Western 
Australian Herbarium. This material, collected from 120 geo-positioned stations, is a valuable baseline for future work including surveys for introduced species in the area (Jones 2004a, b). Although diving was not undertaken in the port operational areas, intertidal collecting was done, and we believe the results obtained are representative of the Dampier region.

Unfortunately, capable marine taxonomists in Western Australia are few in number and poorly supported. For some ecologically important marine organisms (e.g. hard corals, soft corals, polychaetes, etc.) and groups with known fouling organisms (e.g. ascidians, bryozoans, hydroids, etc.) specimens need to be sent to interstate or overseas experts, as there are none in Western Australia. This lack of expertise severely hampers both the baseline assessment of the Western Australian marine biota and the assessment of potential introductions. There can be no substitute for taxonomic expertise and experience. It would be folly to expect that species recognition and assessment of invasive status can be undertaken without input from experienced taxonomists. Furthermore, it is imperative that voucher specimens be retained. These permanent collections permit reassessment of records and allow for update of names following taxonomic revisions. Unvouchered records are of limited value and can only be assessed in light of the level of expertise of the identifier, for the most part a fairly nebulous gauge of a record's worth. Voucher specimens remove all doubt, particularly where future studies may show there are sibling species or presently undescribed native species.

We conclude with a strong recommendation, that continuing baseline taxonomic research and surveys of the Western Australian marine waters be regarded as an essential component of protecting and managing the State's valuable marine environment.

\section{SPECIES LIST}

\section{Algae (Chlorophyta, Heterokontophyta, Rhodophyta)}

\section{Preamble}

The Western Australian marine benthic flora includes numerous species that are widely distributed, particularly so in tropical areas where many of the taxa have a broad Indo-West Pacific distribution. These species could be regarded as cryptogenic (i.e., potentially introduced but their origins presently obscure due to their widespread distribution), but there seems little value in including them in this compendium. Womersley (2003: 499), faced with a similar situation in the southern Australian marine flora, commented
"There are numerous species in all three phyla which are regarded as widely dispersed species rather than adventive (i.e., introduced). These include some species (such as Polysiphonia brodiei) which may be adventive, but they have known to be present for a long time and are known from several localities." While we have not included the majority of these widespread species, we have, however, incorporated cryptogenic species that are known introductions or pest species in other areas.

\section{CHLOROPHYTA}

\section{Class Ulvophyceae (Green Algae)}

$$
\text { Order Bryopsidales }
$$

$$
\text { Family Caulerpaceae }
$$

\section{Caulerpa taxifolia (Vahl) C.Agardh, 1817}

Western Australian records and vouchers

Known from the Abrolhos Islands (PERTH 03985369) and north into tropical WA (PERTH 07117620).

\section{Distribution elsewhere}

Widespread in tropical seas. The invasive strain is thought to have originally come from southern Queensland and has been introduced to New South Wales and South Australia (in addition to overseas locations such as the Mediterranean and California) (Jousson et al. 2000; Cheshire et al. 2002; Millar 2002; Schaffelke et al. 2002). Subtle genetic differences between these populations suggest that several independent introductions have occurred.

\section{Remarks}

This species has been recorded from tropical Western Australia, but it is unlikely to be the invasive strain of $C$. taxifolia. Molecular testing is required to positively identify the invasive strain. No unusually prolific infestations of $C$. taxifolia have been reported and the species has not been seen outside of its expected tropical distribution.

\section{Family Pseudocodiaceae}

\section{Pseudocodium devriesii Weber-van Bosse, 1896}

\section{Western Australian records and vouchers}

Known only from Cottesloe and off Rous Head, Fremantle (PERTH 07259948; 07259697).

\section{Distribution elsewhere}

Known from East London, South Africa eastward to Mozambique; Madagascar (Coppejans et al. 2005). 
Remarks

- This species appears to be restricted to the Rous Head and Cottesloe area, where it forms small clusters in sand associated with rocks. It was first observed in 2000 and its proximity to Fremantle harbour suggests it is probably an introduction. DNA sequence analyses (Verbruggen, pers. comm., 2006) have demonstrated its conspecificity with specimens from South Africa. The population does not appear to be spreading but any expansion should be monitored closely.

\section{Order Ulvales}

Family Ulvaceae

UIva taeniata (Setchell) Setchell and Gardner, 1920

Western Australian records and vouchers

Fremantle, Swan Estuary (Womersley 1984: 149; Phillips 1988: 450, as U. stenophylla; MUCV 1578, 1579).

\section{Distribution elsewhere}

Pacific coast of North America; Hawaiian Islands; Australia; New Zealand.

\section{Remarks}

Ulva is represented by two widespread species that occur sporadically (U. taeniata) or commonly ( $U$. fasciata) in the Perth region. Very little is known of the relationships of these species with overseas populations. UIva taeniata was recorded by Womersley (1984) for the Perth region and subsequently listed by Womersley (2003) as a 'probable adventive species'. Phillips (1988: 450) referred the Womersley (1984) record to $U$. stenophylla and the true identity of the Western Australian entity requires more detailed (probably molecular) comparisons with overseas populations. Whatever the outcome, the species will still be regarded as introduced or cryptogenic, as the native distributon of both species is the Pacific coast of North America.

\section{Ulva fasciata Delile, 1813}

\section{Western Australian records and vouchers}

Swan River Estuary (Phillips, 1988: 436; PERTH). Cryptogenic on the lower west coast of WA (NIMPIS, 2002).

\section{Distribution elsewhere}

Widespread in tropical to temperate seas.

\section{Remarks}

See remarks under $U$. taeniata.

\section{Heterokontophyta}

Class Phaeophyceae (Brown Algae)

Order Chordariales

Family Elachistaceae

Elachista orbicularis (Ohta) Skinner, 1983

Western Australian records and vouchers

King George Sound (PERTH 04156404); Rottnest

I. (Womersley, 1987: 78; PERTH 04156382).

\section{Distribution elsewhere}

Native to Japan; introduced to southern Australia (Rottnest I. and Albany, WA; Port Noarlunga to Port Elliot, SA, and Garie Beach, NSW) (Womersley 1987).

\section{Remarks}

This species forms dark brown tufts on Ecklonia radiata. It is common in the Perth region and was thought to be an introduction from Japan (Womersley 1987). Given its small size and seemingly negligible effect on the host, Elachista orbicularis is unlikely to become a pest species.

\section{Order Dictyosiphonales}

\section{Family Striariaceae}

Striaria attenuata Greville, 1828

Western Australian records and vouchers

Not present; no vouchers.

\section{Distribution elsewhere}

Adelaide, SA, Tas., and Pambula, NSW. temperate N. Atlantic; southern New Zealand; Japan (Womersley 1987)

\section{Remarks}

Jones (1992, table 4) tabulated several species of marine introductions, including this brown alga, citing Skinner and Womersley (1983). Western Australian records of the species are not mentioned in that publication or in Womersley's subsequent Marine Benthic Flora of Southern Australia (1987), and the species does not appear to occur in WA.

\section{Stictyosiphon soriferus (Reinke) Rosenvinge, 1935}

Western Australian records and vouchers

Albany (Skinner and Womersley, 1983; Womersley, 1987: 314; AD A51388).

Distribution elsewhere

North Atlantic; Mediterranean; introduced in 
southern Australia (Albany to Port Phillip Bay, Vic. in harbours) (Womersley 1987).

\section{Remarks}

Thought to be an introduction from the North Atlantic (Womersley 1987: 314), as in southern Australia it is predominantly restricted to harbours. The status of the species in Albany is presently unknown, as it was not mentioned in the CRIMP (1997b) survey of the Port of Albany and has not been the subject of a targeted search.

\section{Order Scytosiphonales}

Family Scytosiphonaceae

\section{Endarachne binghamiae J.Agardh, 1896}

Western Australian records and vouchers

Cottesloe, on intertidal rock (Huisman et al. 2006), Rottnest I. (PERTH 07573286; 07573278).

\section{Distribution elsewhere}

Widespread in temperate and tropical seas.

\section{Remarks}

This species is only recently recorded for WA, from an area close to Fremantle Harbour. It has since also been observed at Rottnest Island. Given its widespread distribution elsewhere, the origins of the Perth specimens of Endarachne will be difficult to assess. Moreover, the superficially similar Petalonia fascia is well known as a winter annual in the Perth region, which might have led to earlier populations of Endarachne being overlooked. Since it has not displayed pest tendencies in other areas and is restricted to intertidal habitats, E. binghamiae is unlikely to become a problem species in WA.

\section{Rhodophyta (Red Algae)}

\section{Class Florideophyceae}

\section{Order Ceramiales}

\section{Family Delesseriaceae}

Cottoniella fusiformis Børgesen, 1930 (also reported as $C$. filamentosa var. fusiformis).

\section{Western Australian records and vouchers}

Houtman Abrolhos and Dampier Archipelago (as C. filamentosa; Huisman, 1997, 2000; Huisman and Borowitzka, 2003; PERTH: MURU DAR 1276).

\footnotetext{
Distribution elsewhere

Widespread in warmer waters.
}

\section{Remarks}

Recorded as adventive by Womersley (2003: 500) based on South Australian records from eastern Gulf St. Vincent. This species is known in WA from many locations. It has a broad distribution in warmer waters and its presence in WA is not unexpected.

\section{Family Rhodomelaceae}

\section{Acanthophora spicifera (Vahl) Børgesen, 1910}

Western Australian records and vouchers

Dawesville (PERTH 07573294); Houtman Abrolhos north (Huisman, 2000; PERTH - MURU DAR 1508).

\section{Distribution elsewhere}

Widespread in tropical and warm temperate seas.

\section{Remarks}

A widespread species in many tropical areas, including the warmer waters of WA, A. spicifera was introduced to the Hawaiian Islands and has become a major pest species, virtually dominating many intertidal and shallow subtidal reef flats. It is generally only encountered sporadically in WA. However, a recent bloom (2007) of $A$. spicifera has occurred at Dawesville, which is of great interest as it is outside the usual range of the species, and the population is very dense (Hosja, pers. comm.). Specimens from the Dawesville population are presently being analysed to assess their relationships with those from northern WA and also with Hawaiian populations.

\section{Order Gigartinales}

\section{Family Acrosymphytaceae}

\section{Acrosymphyton taylorii Abbott, 1962}

Western Australian records and vouchers

Rottnest I.; Houtman Abrolhos (Huisman 2000; PERTH 06559050; 06559077).

\section{Distribution elsewhere}

Widespread in warmer waters of the Indo-West Pacific; Hawaiian Islands (Millar and Kraft, 1984; Huisman, 2000).

\section{Remarks}

Recorded as adventive by Womersley (2003: 500) based on a South Australian record. This species is known in WA from Rottnest Island and some localities further north (e.g. Houtman Abrolhos Islands). It has a broad distribution in warmer waters of the Indo-Pacific and its presence in WA is 
not unexpected. Acrosymphyton taylori is known only from the conspicuous gametophyte phase of the life history, the tetrasporophyte presumably cryptic and presently unknown. Gametophytes are usually spring-summer annuals. As such, A. taylori is similar to several other seasonal red algae found in WA, none of which are regarded as pests.

\section{Family Hypneaceae}

\section{Hypnea musciformis (Wulfen) Lamouroux, 1813}

Western Australian records and vouchers Point Peron (PERTH 07573545; 07573553).

\section{Distribution elsewhere}

Widespread in warmer seas (Guiry and Guiry 2007).

\section{Remarks}

Specimens compatible with descriptions of this species are occasionally common in the Perth region. This species forms blooms in the Hawaiian Islands, probably as a response to increased nutrients. As yet, $H$. musciformis has not been problematic in WA. DNA sequence analyses are being undertaken to assess the relationships between local and overseas specimens.

\section{Family Solieriaceae}

\section{Eucheuma denticulatum (Burman) Collins and Hervey, 1917}

\section{Western Australian records and vouchers}

From the Houtman Abrolhos (rarely), and northward of the North West Cape region (Huisman, 2000; Huisman and Borowitzka, 2003; PERTH 07235445; 06706541).

\section{Distribution elsewhere \\ Widespread in the Indo-Pacific.}

\section{Remarks}

A widespread species in the Indo-Pacific and found in several locations in tropical WA. This species was intentionally introduced to the Hawaiian Islands and has become a major pest. WA populations have not shown similar tendencies.

\section{Order Halymeniales}

Family Halymeniaceae

\section{Grateloupia imbricata Holmes, 1896}

Western Australian records and vouchers Cottesloe (Huisman et al., 2006; PERTH 07573316).
Distribution elsewhere

Native to Japan, introduced to the Mediterranean (Verlaque et al. 2005).

\section{Remarks}

At present known in WA only from a rocky groyne in Cottesloe (Huisman et al. 2006), DNA sequence analyses (De Clerck, pers. comm.) have indicated that the local material is closely related to populations of this species in Japan and the Mediterranean (the latter considered an introduction, Verlaque et al. 2005). Further studies of the extent of this species in WA are required.

\author{
Dinophyta \\ (Dinoflagellates) \\ Class Dinophyceae \\ Order Gonyaulacales \\ Family Gonyaulaceae
}

\section{Alexandrium catenella (Whedon and Kofoid 1936) Balech, 1985}

Western Australian records and vouchers

Listed as occurring in WA in the Schedule of 'Known exotic species in Australian waters' (CRIMP 1997b, 2000); in ballast water of ship arriving at Port Hedland (Hallegraeff and Bolch 1992).

\section{Distribution elsewhere}

Widespread in many temperate seas; cryptogenic in south-eastern Australia (NIMPIS 2002).

\section{Remarks}

Viable cysts of this species were collected and germinated from the ballast tanks of a ship arriving in Port Hedland (Hallegraeff and Bolch 1991, 1992), but it is not known if local populations were established as a result. The species has never been collected directly from WA waters (Hallegraeff 2007; pers. comm.). NIMPIS (2002) indicates only a south-eastern Australian distribution.

Alexandrium minutum (Halim, 1960) Balech, 1989

Western Australian records and vouchers

Bunbury (CRIMP 1997a, as 'cf.'); Bunbury and Geographe Bay, Mandurah, Peel Inlet, Cockburn Sound, Swan River (Hallegraeff and Hosja 1993; NIMPIS 2002).

\section{Distribution elsewhere}

Cryptogenic in the Mediterranean, Spain, New Zealand, east coast of USA, south east Asia and 
parts of south-east Australia, introduced to Tas., parts of SA and southwestern WA (Chang and McClean 1997; Giacobbe et al. 1996; NIMPIS 2002).

\section{Remarks}

This and the following species are recorded sporadically in WA waters, either as the swimming, flagellated stage or as benthic cysts. In other areas of the world, these species form dense toxic blooms in shallow lagoons and brackish marine embayments that may be accompanied by mortality of fish and shellfish (Sorokin et al. 1996) and in outbreaks of paralytic shellfish poisoning (PSP) (Anderson et al. 1983). No blooms have been reported in WA. Monitoring is routinely undertaken of commercial mussel and oyster farming areas in WA.

\section{Alexandrium tamarense (Lebour) Balech, 1985}

Western Australian records and vouchers

Bunbury (CRIMP 1997a, as 'cf.'); Fremantle (CRIMP 2000). NIMPIS (2002) lists this species as being possibly introduced into the south coast and lower west coast of WA.

\section{Distribution elsewhere}

Native range unknown, cryptogenic almost worldwide in temperate coastal waters (Turpin et al. 1978; Anderson et al. 1983; Schrey et al. 1984; Ogata et al. 1987; Anderson et al. 1994; Sorokin et al. 1996; Adachi et al. 1999), including southern Australia (Parry et al. 1997; Cohen et al. 2001; Aquenol 2001; Ruiz Sebastian et al. 2005).

\section{Remarks}

Alexandrium tamarense - like cells were found in the preserved Fremantle port survey collections, but obviously these could not be cultured, and cysts from Fremantle were also never successfully germinated (Hallegraeff 2007; pers. comm.). Thus this record remains to be confirmed genetically. Alexandrium tamarense is linked with paralytic shellfish poisoning (PSP) (Giacobbe et al. 1996; Chang and McClean 1997).

\section{Order Gymnodiniales}

Family Gymnodiniaceae

\section{Gymnodinium catenatum Graham, 1943 (now G. microreticulatum)}

Western Australian records and vouchers

Albany (CRIMP 1997b); Bunbury (CRIMP 1997a).

\section{Distribution elsewhere}

Native range unknown, cryptogenic in cool temperate to tropical/subtropical seas virtually worldwide (Matsuyama et al. 1999), including parts of southern Australia. Introduced to Tasmania (Hallegraeff and Bolch 1991; Hallegraeff et al. 1997; McMinn et al. 1997; Lovejoy et al. 1998; Bolch et al. 1999; Bolch and Reynolds 2002).

\section{Remarks}

Gymnodinium catenatum cysts were reported in high concentrations from several locations in Albany and Bunbury by CRIMP (1997a, b), but the original identification was of "Gymnodinium catenatum - like cysts" (Hallegraeff 2007; pers. comm., including emphasis). This taxon was subsequently described as the new, non-toxic species Gymnodinium microreticulatum (Bolch et al. 1999). Gymnodinium catenatum has never been seen in WA waters (Hallegraeff 2007; pers. comm.).

\section{Bryozoa (Bryozoans) \\ Class Gymnolaemata \\ Order Cheilostomatida \\ Family Aeteidae}

\section{Aetea anguina Linnaeus, 1758}

Western Australian records and vouchers Shark Bay (Wyatt et al. 2005).

\section{Distribution elsewhere}

Widely distributed throughout most seas, apparently only absent from polar regions, common in European seas (Osburn 1950; Ryland 1965; Ryland and Hayward 1977); in southern Australia from Port Phillip Bay, Vic. (Black 1971; Vigeland 1971; Bock 1982; Hewitt et al. 2004).

\section{Remarks}

A common but inconspicuous member of the fouling fauna, usually found growing over the surface of algae, other invertebrates, rocks, shells, wooden structures and almost any submerged object (Ryland 1965; Ryland and Hayward 1977; Bock 1982).

\section{Family Beaniidae}

Beania mirabilis Johnston, 1840

Western Australian records and vouchers Port Hedland (WAM 30558). 
Distribution elsewhere

Widespread in warm and warm temperate seas (Osburn 1950; Ryland and Hayward 1977; Winston 1982).

\section{Remarks}

An inconspicuous species that grows on a variety of surfaces but is probably often overlooked (Ryland and Hayward 1977; Winston 1982).

\section{Family Bugulidae}

\section{Bugula flabellata (Thompson in Gray, 1848)}

\section{Western Australian records and vouchers}

Albany (CRIMP 1997b; WAM 30985); Bunbury (CRIMP 1997a; WAM 30530; 32085); Fremantle and Cockburn Sound (CRIMP 2000; WAM 30812; $32846)$. South coast and lower west coast of WA (NIMPIS 2002).

\section{Distribution elsewhere}

Possibly native to Atlantic and Mediterranean coasts. Widely distributed in warm and temperate seas (Ryland 1965; Ryland and Hayward 1977; Gordon 1986; Gordon and Mawatari 1992); in Australia from Port Adelaide, SA (Allen 1953; Brock 1985), Port Phillip Bay, Vic. (Keough and Ross 1999; Cohen et al. 2001; Hewitt et al. 2004) and Eden to Port Stephens, NSW (Allen and Wood 1950).

\section{Remarks}

Found almost invariably attached to other bryozoans. Occurs commonly on rocky shores near low water mark and among the epibenthos of inshore waters (Ryland and Hayward 1977); mainly found on stones, shells etc, occasionally on harbour structures, from low water mark and coastal waters (Ryland 1965).

\section{Bugula neritina (Linnaeus, 1758)}

\section{Western Australian records and vouchers}

Esperance (Western Australian Museum, 2002; Campbell 2003b; WAM 30570; 30572); Albany (CRIMP 1997b; WAM 30959; 30968); Bunbury (WAM 4973; 4974); (CRIMP 1997a; WAM 32071; 32080); Fremantle (CRIMP 2000; WAM 4987); Cockburn Sound (WAM 30813); Shark Bay (Wyatt et al. 2005); Geraldton (WA Museum, 2001; Campbell, 2003a); Port Hedland (CRIMP 1999; DALSE 2004); Dampier (Mackie et. al. 2006). Introduced into all areas of WA (NIMPIS 2002).

\section{Distribution elsewhere}

Widely distributed throughout most seas worldwide, except in cold polar and subarctic/ subantarctic regions (Osburn 1950; Ryland 1965; Ryland and Hayward 1977; Winston 1982; Gordon 1986; Keough 1989; Gordon and Mawatari 1992); in Australia from most areas (Keough and Ross 1999) including Port Phillip Bay, Geelong, Portland, Vic. (Black 1971; Vigeland 1971; Parry et al. 1997; Currie et al. 1998; Cohen et al. 2001; Hewitt et al. 2004); Port Adelaide, SA (Brock, 1985); Port Hacking, Port Jackson, Port Kembla, NSW (Allen and Wood 1950; Vail and Wass 1981; Moran and Grant 1993); and Launceston, Tas. (Aquenol 2001). Genetic analysis suggests a common source for globally widespread introductions (Mackie et. al. 2006).

\section{Remarks}

Found worldwide in warm water ports and harbours, this is a serious and common fouling organism that grows on a wide variety of substrata (Ryland 1965; Ryland and Hayward 1977; Bock 1982; Winston 1982).

\section{Bugula stolonifera Ryland, 1960}

\section{Western Australian records and vouchers}

Esperance (Western Australian Museum, 2002; Campbell 2003b; WAM 30582; 30583); Albany (WAM 30983; 30984); Bunbury (WAM 30974; 32105); Shark Bay (Wyatt et al. 2005); Port Hedland (WAM 30634; CRIMP 1999; WAM 32176; 32187).

\section{Distribution elsewhere}

Mediterranean Sea, Adriatic Sea, southern Britain, Ireland, Ghana, Massachusetts to Florida, Gulf of Mexico, Brazil, Panama Canal; New Zealand, South Australia (Ryland 1965; Ryland and Hayward 1977; Winston 1982; Gordon 1986; Gordon and Mawatari 1992); in Australia known from Port Adelaide, SA (Brock 1985) and Port Phillip Bay, Vic. (Hewitt et al. 2004).

\section{Remarks}

This is a common fouling species, mainly found in ports and harbours on submerged structures where colonies are commonly associated with $B$. neritina (Ryland 1965; Ryland and Hayward 1977). It is less tolerant of warm temperatures than that species (Winston 1982).

\section{Family Candidae}

\section{Tricellaria inopinata Hondt and Occhipinti Ambrogi, 1985}

Western Australian records and vouchers Port Hedland (WAM 30555). 
Distribution elsewhere

Origin: Probably Pacific, known to be invasive in New Zealand and Europe (Dyrynda et al. 2001); cryptogenic in southern Australia (Zibrowius 1991; Aquenol 2001 citing a pers. comm. from P. Bock).

\section{Remarks}

Bock (cited in Aquenol 2001) indicates that this is a cosmopolitan species that has only recently been distinguished from several closely related taxa, and that many of the records of $T$. occidentalis may represent $T$. inopinata. Further work is required to establish the distributions of these species in Australia.

\section{Tricellaria occidentalis (Trask, 1857)}

Western Australian records and vouchers

Fremantle (CRIMP 2000; WAM 32702; 30814);

Barrow I. (Wells and Huisman 2004; Western Australian Museum 2005); (WAM 8520; no location given).

\section{Distribution elsewhere}

Known from British Columbia to California, Japan, China, New Zealand, Venice, Italy (Osburn 1950; Gordon 1986); in Australia from SA and Port Phillip Bay, Vic. (Gordon and Mawatari 1992; Hewitt et al. 2004).

\section{Remarks}

See under $T$. inopinata.

\section{Family Cryptosulidae}

\section{Cryptosula pallasiana (Moll, 1803)}

Western Australian records and vouchers

Albany (CRIMP 1997b; WAM 30994; 30996; 32029); Bunbury (CRIMP 1997a; WAM 30528; 32102; 32359); Fremantle (CRIMP 2000; WAM $30804 ; 32803)$. South coast and lower west coast (NIMPIS 2002).

\section{Distribution elsewhere}

Widespread around the world, particularly in ports, harbours and estuaries (Ryland 1965; Hayward and Ryland 1979; Winston 1982; Gordon 1989; Gordon and Mawatari 1992); in Australia from the south coast (Bock 1982), including Port Adelaide, SA (Brock 1985) and Port Phillip Bay and Western Port, Vic. (Keough and Ross 1999; Hewitt et al. 2004); Sydney Harbour, NSW (Keough and Ross 1999).

\section{Remarks}

This is a common and well-known component of the fouling fauna that can be found encrusting on virtually all solid surfaces in the intertidal or shallow subtidal, including boat hulls (Ryland 1965; Hayward and Ryland 1979; Bock 1982; Gordon 1989; Gordon and Mawatari 1992); its distribution may be related to proximity to shipping lanes (Winston 1982).

\section{Family Electridae \\ Conopeum seurati (Canu, 1928)}

Western Australian records and vouchers

Esperance (Western Australian Museum 2002; Campbell 2003b; WAM 30568); Shark Bay (Wyatt et al. 2005).

\section{Distribution elsewhere}

Estuarine habitats in Britain, northern Europe, Mediterranean, New Zealand, Northeast Pacific, Florida (Ryland and Hayward 1977; Winston 1982; Gordon 1986; Gordon and Mawatari 1992); elsewhere in Australia from Port Phillip Bay, Vic. (Hewitt et al. 2004).

\section{Remarks}

This species is tolerant of extreme fluctuations in salinity and temperature (Ryland and Hayward 1977; Gordon and Mawatari 1992).

\section{Family Epistomiidae}

\section{Synnotum aegyptiacum (Audouin, 1826)}

Western Australian records and vouchers Port Hedland (WAM 30551).

\section{Distribution elsewhere}

Widespread in warm waters, including Indonesia, Timor, Singapore, Japan, Indian Ocean, Red Sea, Mediterranean Sea, Brazil, Florida, California (Osburn 1950; Gordon 1984); in Australia from Vic. and NSW (Gordon 1984).

\section{Family Savignyellidae}

\section{Savignyella lafontii (Audouin, 1826)}

Western Australian records and vouchers

Shark Bay (Wyatt et al. 2005); Barrow I. (Wells and Huisman 2004; Western Australian Museum 2005); Port Hedland (WAM 30556; 32310).

\section{Distribution elsewhere}

Widely distributed in warmer waters (Osburn 1952; Winston 1982; Wyatt et al. 2005). 


\section{Remarks}

This species is usually found associated with algae, sponges, Zoobotryon and hydroids; its delicate colonies are not usually obvious until examined microscopically (Winston 1982).

\section{Family Schizoporellidae}

\section{Schizoporella errata (Waters, 1878)}

\section{Western Australian records and vouchers}

Esperance (Western Australian Museum 2002; Campbell 2003b; WAM 30566; 30573); Albany (WAM 30541; 30535; 30547); Bunbury (WAM 30533); Fremantle Harbour (CRIMP 2000; WAM 33011); Geraldton (WA Museum 2001; Campbell 2003a); Shark Bay (Wyatt et al. 2005).

\section{Distribution elsewhere}

Widespread in warm temperate to subtropical seas (Ryland 1965; Hayward and Ryland 1979; Gordon and Mawatari 1992); in Australia known from Port Adelaide, SA (Brock 1985); Port Phillip Bay, Vic. (Hewitt et al. 2004).

\section{Remarks}

A well known fouling species, mostly found in shallow water in ports and harbours (Ryland 1965; Hayward and Ryland 1979).

\section{Schizoporella unicornis (Johnston, 1847)}

\section{Western Australian records and vouchers}

Esperance (Western Australian Museum, 2002; Campbell, 2003b; WAM 30567; 30571); Albany (CRIMP 1997b; WAM 32633); Bunbury (CRIMP 1997a; WAM 30532; 30534; 32104); WA (Pollard and Hutchings 1990b); Fremantle Harbour (Allen 1953). South coast and lower west coast of WA (NIMPIS 2002).

\section{Distribution elsewhere}

Cryptogenic in Japan and colder waters of the eastern Atlantic; introduced to the northeast Pacific (including the Hawaiian Is), west Atlantic (Osburn 1952; Ryland 1965; Sutherland 1978; Hayward and Ryland 1979; Winston 1982; Hurlbut 1991); and eastern and soutwestern Australia (e.g., Port Adelaide, SA, Port Phillip Bay, Vic., Port Hacking and Port Jackson, NSW, Great Barrier Reef, Qld.) (Allen 1953; Vail and Wass 1981; Brock 1985; Pollard and Hutchings 1990b; Hewitt et al. 2004).

\section{Remarks}

A principal fouling species, recorded widely but perhaps often erroneously as there is some confusion with Schizoporella errata (Ryland 1965; Hayward and Ryland 1979; Winston 1982). There is some evidence that this species arrived in Sydney on two Japanese vessels captured during the war (Allen 1953).

\section{Family Watersiporidae}

\section{Watersipora arcuata Banta, 1969}

\section{Western Australian records and vouchers}

Esperance (Western Australian Museum 2002; Campbell 2003b; WAM 30569); Albany (CRIMP 1997b); Bunbury (CRIMP 1997a; WAM 32082; 32091); Fremantle Harbour (CRIMP 2000; WAM 32836; Mackie et al. 2006); Geraldton (WA Museum 2001; Campbell 2003a); WA (Pollard and Hutchings $1990 \mathrm{~b})$. South coast and lower west coast of WA (NIMPIS 2002).

\section{Distribution elsewhere}

Widely distributed in warmer seas (Banta 1969; Winston 1982; Gordon 1989; Gordon and Mawatari 1992); in Australia recorded from several locations in southern Australia (Bock 1982), including Port Adelaide, SA (Brock 1985), Port Phillip Bay, Vic. (Hewitt et al. 2004), Port Hacking, Port Jackson and Port Kembla, NSW (Vail and Wass 1981; Moran and Grant 1993) and Qld. (Pollard and Hutchings 1990b).

\section{Remarks}

This is a common and well-known fouling organism that can grow rapidly on almost any surface, including copper anti-fouling paint (Winston 1982; Bock 1982; Gordon 1989; Gordon and Mawatari 1992).

\section{Watersipora subtorquata (d'Orbigny, 1852)}

Western Australian records and vouchers

Albany (WAM 30539); Bunbury (CRIMP 1997a; WAM 30527); Fremantle (CRIMP 2000; Mackie et. al. 2006); Geraldton (WA Museum, 2001; Campbell 2003a); Shark Bay (Wyatt et al. 2005).

\section{Distribution elsewhere}

Brazil, West Indies, Bermuda, California, Cape Verde Islands, Japan, Torres Strait, Mediterranean, Great Barrier Reef, New Zealand (Gordon 1989; Zibrowius 1991; Gordon and Mawatari 1992); in Australia from the Great Barrier Reef, Qld. (Gordon and Mawatari 1992); Port Phillip Bay and Portland, Vic. (Parry et al. 1997; Currie et al. 1998; Keough and Ross 1999; Hewitt et al. 2004); Port Lincoln and Adelaide, SA (Keough and Ross 1999); and Launceston, Tas. (Aquenol 2001). 


\section{Remarks}

Grows on a wide variety of substrata. Exact distribution uncertain because of taxonomic difficulties (Gordon and Mawatari 1992; Mackie et. al. 2006).

\section{Order Ctenostomatida}

$$
\text { Family Vesiculariidae }
$$

Amathia distans Busk, 1886

Western Australian records and vouchers

Port Hedland (CRIMP 1999; WAM 30559; 32445; DALSE 2004). Lower west coast and Pilbara of WA (NIMPIS 2002).

\section{Distribution elsewhere}

Apparently native to the warmer waters of the west Atlantic; cryptogenic in the east Atlantic and introduced widely, including France, the Mediterranean and Red Seas, the Atlantic coast of America from North Carolina to Brazil, Puget Sound Washington, Southern California, South Atlantic, Java, Indonesia, New Zealand, and various locations around Australia (Osburn 1953; Winston 1982; Gordon and Mawatari 1992).

\section{Remarks}

Amathia distans forms pale-brownish transparent colonies growing on other bryozoans, algae or more usually under sandstone boulders, on oyster valves and polychaete tubes (Gordon and Mawatari 1992). This species is not considered a pest in Australia and its potential impact on the environment is regarded as low (CRIMP 1999).

\section{Amathia vidovici Heller, 1867}

Western Australian records and vouchers Port Hedland (WAM 30559; WAM 30629).

\section{Distribution elsewhere}

Recorded from the Western Atlantic, from Massachusetts to Gulf of Mexico, the Caribbean, the Pacific from southern California to the Galapagos, the Mediterranean, Adriatic, East Atlantic and Indian Ocean (Osburn 1953; Winston 1982).

\section{Bowerbankia gracilis Leidy, 1855}

Western Australian records and vouchers Port Hedland (WAM 30552).

\section{Distribution elsewhere}

Widely distributed around the world, mostly in shallow water (Osburn 1953; Ryland 1965;
Winston 1982; Gordon 1986; Gordon and Mawatari 1992), in Australia from Port Adelaide, SA (Brock 1985).

Remarks

This species occurs in brackish as well as marine waters and grows on a wide variety of surfaces (Ryland 1965; Winston 1982), its colonies appearing as a characteristic fine grey 'fur' just visible to the naked eye (Gordon and Mawatari 1992).

\section{Zoobotryon verticillatum della Chiaje, 1828}

Western Australian records and vouchers

Port Hedland (WAM 30550; 32461); Shark Bay (Wyatt et al. 2005).

\section{Distribution elsewhere}

Widely distributed in warm waters, including the Mediterranean and Adriatic where it is common in many of the major ports (Osburn 1953; Ryland 1965; Winston 1982; Gordon and Mawatari,1992); in Australia from several locations in southern Australia (Bock 1982) including Port Adelaide, SA (Brock 1985); Port Phillip Bay, Vic. (Hewitt et al. 2004); Port Hacking and Port Jackson, NSW (Vail and Wass 1981).

\section{Remarks}

A common fouling species of warmer waters, typically found in ports and harbours growing on any submerged object (Ryland 1965; Bock 1982).

\section{Arthropoda}

Class Malacostraca (Amphipods, Isopods and
Crabs)

Order Isopoda (Isopods)

Family Cirolanidae

\section{Cirolana harfordi (Lockington, 1877)}

Western Australian records and vouchers

Swan River (Bruce 1986; Poore and Storey 1999; Furlani 1996); Fremantle Harbour (Hass and Jones 2000). Introduced into the lower west coast of WA (NIMPIS 2002).

\section{Distribution elsewhere}

First described from California, distributed in western North America from British Columbia to Baja California, subsequently recorded from Japan, eastern Russia and Malaysia (Johnson 1976; Poore and Storey 1999); in Australia from Port Phillip Bay, Lorne, and Bass Strait, Vic. (Bruce 1986; Hutchings 
et al., 1987; Currie et al., 1998; Cohen et al., 2001; Hewitt et al., 2004) and Waverton, NSW (Bruce, 1986). Australian records mainly limited to ports.

\section{Remarks}

Initially discovered in the Swan River in 1980 (Bruce, 1986) and subsequently in Fremantle Harbour in 1991 (Hass and Jones, 2000). Collected under rocks and amongst mussels, from ship hulls (Bruce, 1986); this is a voracious scavenger that has the potential to be a pest species by reaching high population densities (Johnson, 1976; Furlani, 1996).

\section{Family Sphaeromatidae}

\section{Paracerceis sculpta (Holmes, 1904)}

\section{Western Australian records and vouchers}

Esperance (Western Australian Museum, 2002; Campbell, 2003b; WAM 34505; 34506); Bunbury, Mandurah, Fremantle, Port Denison, 1996 (Hass and Jones, 2000); Bunbury (WAM 23303; CRIMP; WAM 34508 - 34511; 35140 - 35187); Fremantle (CRIMP; WAM 35839; 35846). Lower west coast of WA (NIMPIS, 2002).

\section{Distribution elsewhere}

Originally described from California, and since recorded elsewhere in tropical Pacific and Atlantic (Brazil, Mexico, Hawaiian Is.); possibly introduced to the Mediterranean (Zibrowius, 1991); in Australia from Port Phillip Bay, Vic. (Hewitt et al., 2004); Townsville, Qld. (Harrison and Holdich, 1982b; Hutchings et al., 1987; Pollard and Hutchings, 1990b; Furlani, 1996; Poore and Storey, 1999; Hewitt and Campbell, 2001).

\section{Remarks}

Like other sphaeromatids, females and juveniles are almost impossible to identify without accompanying males. This species is so rarely recorded in Australia that nothing is known of its biology here (Poore and Storey, 1999).

\section{Paradella dianae (Menzies, 1962)}

\section{Western Australian records and vouchers}

Bunbury (WAM 23302; WAM 16781; 23302); Swan River (Harrison and Holdich, 1982a; Pollard and Hutchings, 1990b; Zibrowius, 1991; Furlani, 1996); Fremantle Harbour, Bunbury Harbour (Hass and Knott, 1998). Other vouchers QM W7938, QM W3746. South coast and lower west coast of WA (NIMPIS, 2002).

\section{Distribution elsewhere}

Originally described from Baja California and subsequently reported from California, the
Marshall Islands, Quéensland, the Arabian Sea, Brazil and Puerto Rico, recorded in the Mediterranean for the first time from Alexandria, Egypt (Zibrowius, 1991); in Australia from Townsville and North Stradbroke Island, Qld. (Harrison and Holdich, 1982a; Hutchings et al., 1987; Furlani, 1996).

\section{Remarks}

First discovered in the Swan River in 1980 (Harrison and Holdich, 1982a), subsequently in Fremantle and Bunbury Harbours in 1994/95 (Hass and Knott, 1998). Grows amongst barnacles, bryozoans and rock oysters on rocks and artificial structures, appears to be tolerant of a wide variety of ecological conditions (Harrison and Holdich, 1982a).

\section{Sphaeroma serratum Fabricius, 1787}

\section{Western Australian records and vouchers}

Esperance (Western Australian Museum, 2002; Campbell, 2003b; WAM 36953); Swan River (Holdich and Harrison, 1983; Hutchings et al., 1987; Pollard and Hutchings, 1990b; Hass and Knott, 1998; Furlani, 1996); Jurien Bay (Hass, 2007).

\section{Distribution elsewhere}

Widespread (Pollard and Hutchings, 1990b).

\section{Remarks}

First discovered in the Swan River in 1980 (Holdich and Harrison, 1983), subsequently rediscovered in 1994/95 (Hass and Knott, 1998) and then in Jurien Bay in 2006 (Hass, 2007).

\section{Order Amphipoda (Amphipods) \\ Family Corophiidae}

\section{Monocorophium acherusicum (Costa, 1857)}

Western Australian records and vouchers

Bunbury, Swan River (Poore and Storey, 1999). Lower west coast of WA (NIMPIS, 2002).

\section{Distribution elsewhere}

Native to the northeast Atlantic and Mediterranean region, cryptogenic on both coasts of North America, introduced to various localites in the southwestern Atlantic, Indian and western Pacific oceans (Hurley, 1954; Barnard, 1970); in Australia from the southeast and southwest, e.g., Port Jackson, Port Kembla and Botany Bay, NSW; eastern Tasmania (Poore and Storey, 1999); Gippsland Lakes, Mallacoota, Western Port and Port Phillip Bay, Vic. (Fearn-Wannan, 1968; Cohen et al., 2001; Hewitt et al., 2004). 


\section{Remarks}

This species is commonly found in association with ships, buoys and around wharf structures (Fearn-Wannan 1968), its distribution tracing some major shipping routes (Hurley 1954).

\section{Monocorophium insidiosum (Crawford, 1937)}

Western Australian records and vouchers

Swan River (Poore and Storey 1999). Lower west coast of WA (NIMPIS 2002).

\section{Distribution elsewhere}

Widely distributed, especially in harbours (Barnard 1970; Alonso de Pina 1997); in Australia from Port Kembla, NSW, Port Phillip Bay and Western Port, Vic., and Port MacDonnell, SA (Poore and Storey 1999; Cohen et al. 2001; Hewitt et al. 2004).

\section{Remarks}

An estuarine species, occurring intertidally and subtidally on mud sediments or among algae and seagrasses. Most Australian records are from harbours or estuaries (Poore and Storey 1999).

\section{Monocorophium sextonae (Crawford, 1937)}

\section{Western Australian records and vouchers}

Bunbury Harbour (Poore and Storey 1999). Lower west coast of WA (NIMPIS 2002).

\section{Distribution elsewhere}

Northeast Atlantic (England, Scotland, Ireland, France, The Netherlands, the Mediterranean, Portugal) and New Zealand (Hurley 1954; Costello 1993) in Australia from Jervis Bay, NSW; Port Phillip Bay, Point Henry, Queenscliff, and Western Port, Vic.; Georges Bay and Launceston, Tas. (Poore and Storey 1999; Aquenol 2001; Hewitt et al. 2004).

\section{Remarks}

Monocorophium sextonae is a tube dwelling amphipod, found on kelp holdfasts, sponges and artificial substrata (Costello 1993). Hurley (1954) suggested that the species had possibly been introduced to Europe from New Zealand. Its natural distribution is uncertain and it may be native to Australia and New Zealand (Poore and Storey 1999).

\section{Order Decapoda (Crabs)}

\section{Family Portunidae}

\section{Carcinus maenas (Linnaeus, 1758)}

Western Australian records and vouchers

Swan River, 1965 (Zeidler 1978; Furlani 1996; Hass and Jones 2000; WAM 14833). WA (Pollard and Hutchings 1990b). Voucher specimen(s): Presumably AM P36248-9, P36089. NIMPIS (2002) has a blank area indicated on the lower west coast of WA.

\section{Distribution elsewhere}

Originally from Europe, although now widespread elsewhere; in Australia from Port River - West Lakes, SA, Port Phillip Bay, Vic. to Sydney, NSW, and Tas. (Fulton and Grant 1900, 1901; Allen 1953; Zeidler 1978; Rozenweig 1984; Hutchings et al. 1986, 1987, 1989; Pollard and Hutchings 1990b; Furlani 1996; Currie et al. 1998; Ahyong 2005; Cohen et al. 2001; Aquenol 2001; Hewitt et al. 2004).

\section{Remarks}

In 1965 the European shore crab, Carcinus maenas, was recorded from the Swan River Estuary, WA. No populations appear to have established (CRIMP 1997b: 7) and the species is presently known from only one specimen in WA (Hass and Jones 2000). This introduced species, however, has become established in the south-eastern states of Australia, where it out competes native species (Fulton and Grant 1901; Zeidler 1978, 1988; Furlani 1996; Walters 1996; Ahyong 2005). The method of introduction of C. maenas into Western Australia is not known, but the species is suspected to have been introduced into Australia from Europe, on the hulls of the ships which brought the first settlers (Fulton and Grant 1901).

\section{Family Inachoididae}

\section{Pyromaia tuberculata (Lockington, 1877)}

\section{Western Australian records and vouchers}

Cockburn Sound (Morgan 1990; Furlani 1996; Poore and Storey 1999; Hass and Jones 2000; WAM 19338). Lower west coast of WA (NIMPIS 2002).

\section{Distribution elsewhere}

Native to west coast of the Americas ranging from San Francisco Bay, California to Utria Bay, Colombia; widely distributed in the temperate and sub-tropical Pacific and South Atlantic, Brazil, Japan, New Zealand (Morgan 1990; Poore and Storey 1999); in Australia from Port Phillip Bay, Vic. (Hass and Jones 2000; Furlani 1996; Poore and Storey 1999; Hewitt et al. 2004).

\section{Remarks}

In Western Australia, the American spider crab, Pyromaia tuberculata, was introduced to Cockburn 
Sound in 1978 via ballast water (Morgan 1990). This species is now also recorded as an introduction in Port Phillip Bay, Vic. (Walters 1996), but in WA it is only known by the specimen reported by Morgan in 1990.

\author{
Class Maxillopoda \\ Subclass Cirripedia (Barnacles) \\ Order Sessilia \\ Family Balanidae
}

\section{Amphibalanus amphitrite (Darwin, 1854)}

\section{Western Australian records and vouchers}

As Balanus amphitrite: Garden I. (Lewis 1981); from Esperance area to Dampier Archipelago (Jones 1987a, 1987b, 1990a, 1990b, 1999a, 2002, 2004b, 2005; Jones and Hewitt 2001; WAM 668; 778, 10092; 6926; 12141); Port Hedland (CRIMP 1999; DALSE 2004) and Broome and Kimberley area (Jones 1991, 1992b, 2004b; WAM 20944; 21166-21168).

\section{Distribution elsewhere}

Indian Ocean to southwestern Pacific; regarded as an introduced species in New Zealand (Foster 1978) and Australia (Jones 1992a). Cosmopolitan in tropical and warm temperate seas (Jones 1990a).

\section{Remarks}

A cosmopolitan, cryptogenic species, occurring in tropical, subtropical and temperate seas. In Australia it is recorded from the waters of WA, SA, Vic., NSW, QId. and the NT. The species occurs intertidally to a depth of $9 \mathrm{~m}$, in quiet bays and estuaries protected from rough surf. It attaches to a variety of animate (e.g. decapod crustaceans, molluscs) and inanimate (e.g. rocks, buoys, cables) substrata and is an important fouling species of boats and marine installations.

\section{Amphibalanus improvisus (Darwin, 1854)}

\section{Western Australian records and vouchers}

As Balanus improvisus: Southwestern Australia (Bishop 1951; Hutchings et al. 1987; Jones 1992a; Furlani 1996; no vouchers available).

\section{Distribution elsewhere}

Atlantic coasts of North America; North Atlantic; Europe; W Africa to Cape of Good Hope; Mediterranean; Black Sea; Red Sea; Baltic Sea; southern Australia (Pollard and Hutchings 1990b); Japan; NW coast of USA (Washington to San Francisco); Ecuador.

\section{Remarks}

The Australian record is historical and the species has not been recollected (Jones 1992a). Bishop (1951) suggested that the Atlantic brackish-water species Balanus improvisus had become established in "one of the southern Australian ports" during the 1940s. However, from fouling studies of submerged surfaces on the eastern Australian coast, Allen (1953) could not substantiate this claim and there are no subsequent records of this species occurring in Australian waters. There are no specimens lodged in any of the Australian state museums (pers. obs., DSJ). If the species is found in Australia in the future, it would be through a new introduction.

\section{Amphibalanus reticulatus (Utinomi, 1967)}

Western Australian records and vouchers

As Balanus reticulatus: Cockburn Sound (WAM 33156; 33157); Swan Estuary, Nedlands (WAM 32451); Yanchep (Jones 1990b; WAM 17826); Leonardo Da Vinci Geraldton Port (Jones 2002a; WAM 34004; 34007); Barrow I. (Jones 2005); Dampier Archipelago (WAM 27238); Burrup Peninsula (WAM 27336; 27339); Cape Preston (WAM 27355); Dampier (WAM 27354; 25750); Cape Lambert, Port Hedland (Jones, unpublished data); Cocos-Keeling Islands (WAM 29046); Christmas Island (WAM 33372; 33373).

\section{Distribution elsewhere}

Cosmopolitan in tropical waters and a circumtropical fouling species (Jones 1990a).

\section{Remarks}

This circumtropical fouler was first recorded in Australian waters on fouling panels at the North Barnard Islands, Qld. (Lewis 1979, as B. amphitrite; 1981b). First records in WA were from Yanchep Marina (Jones 1990a, 1991; Jones et al. 1990) and, more recently, the species has been recorded from the Dampier Archipelago (Jones 2004b) and Barrow Island (Jones 2005). The means of introduction of $A$. reticulatus into Australian waters is unknown, but Utinomi (1967) has suggested that the widespread distribution of this Japanese species is via ship transport.

\section{Megabalanus ajax (Darwin, 1854)}

\section{Western Australian records and vouchers}

Shark Bay (WAM 32490; 32496); Muiron Is. (Jones and Hewitt 1996; WAM 22345); Barrow I. (Jones 2005); Dampier Archipelago (Jones 2004b; WAM 22345-22347); Broome (WAM 32495). 
Distribution elsewhere

Widespread in the Indo-west Pacific.

\section{Remarks \\ Megabalanus ajax attaches mainly to corals (e.g. Millipora complanata Lamarck) but also occasionally occurs as a fouler of ships hulls (Jones 1992b, 2004b, 2005). The species has been recorded from Queensland as well as from WA. The possible vector for the introduction of this species to WA waters is shipping.}

\section{Megabalanus rosa (Pilsbry, 1916)}

\section{Western Australian records and vouchers}

Garden I. (WAM 33163; 33165; 33189); Shark Bay (WAM 15848; 15855); Barrow I. (Jones 2005); Dampier Archipelago (WAM 27205; 27241; 27292); Port Hedland (WAM 15847); Cockatoo I. (AM P 20075). WA central and north-west coast (Jones et al. 1990; Jones 1992a). Introduced into the entire west and Pilbara coasts of WA (NIMPIS 2002).

\section{Distribution elsewhere}

Japan; China; Taiwan (Pollard and Hutchings 1990b); Australia (Allen 1953); in Australia from lower east coast, NSW (Jones et al. 1990; Jones 1992a).

\section{Remarks}

Allen (1953) recorded the Japanese fouler Megabalanus rosa, together with $M$. volcano and Amphibalanus albicostatus, on aircraft carriers and other vessels returning to Australia after service in Korean and Japanese waters. However, it is not known where these vessels docked and Allen (1953) did not record these species as establishing on the Australian coastline. The appearance of the species in WA waters appears to be relatively recent, the first specimens being collected in 1981 (Jones 1992a). Megabalanus rosa is now established on the central and the north-western coast of WA (Garden Island; Shark Bay, Barrow Island, the Dampier Archipelago, Port Hedland and Cockatoo Island), as well as on the lower east coast of Australia (Woolongong, Port Botany and Port Kembla in NSW) (Hass and Jones 2000; Jones 2000b, 2001a, 2001b, 2004b, 2005; Jones et al. 1990). These are all areas that receive international shipping and, therefore, ship fouling is the most probable transport mechanism for this species.

\section{Megabalanus tintinnabulum (Linnaeus, 1758)}

\section{Western Australian records and vouchers}

Esperance (WAM 32482); Albany (WAM 16098); Rockingham (WAM 16132); Cockburn Sound (Jones 1992a; WAM 12188); Fremantle (Jones 1999a; WAM 25240); Cottesloe (WAM 3919); Port Gregory (WAM 12153); Dongara (WAM 14546); Geraldton (WAM 33766); Shark Bay (WAM 7484); Carnarvon (WAM 23789); Pt Cloates, Ningaloo Reef (WAM 13265); North West Cape (WAM 12159); Warroora Station, Ningaloo Reef (WAM 16139); Coral Bay (WAM 16214); Exmouth Gulf (WAM 21180); Muiron Islands (Jones and Hewitt 1996; WAM 22287); Onslow (WAM 7556); Barrow I. (Jones 1992a; Jones 2005; WAM 14242); Montebello Islands (Jones and Berry 2000; WAM 23404); Dampier (Jones 1992a; WAM 12151); Roebourne (WAM 21178); Cape Lambert (WAM 21184); Port Hedland (CRIMP 1999); Broome (WAM 12210); Port Walcott (WAM 14433); Cockatoo I. (Jones 1992a); Yampi Sound, Kimberley (WAM 16093); Mary Anne Passage (WAM 12191); Kimberley (Jones and Hewitt 1997; WAM 22978); King Sound, Derby (WAM 32674); Bonaparte Archipelago (WAM 16138); Buccaneer Archipelago (WAM 21013); Cocos - Keeling Islands (WAM 33133); Flying Fish Cove, Christmas Island (WAM 20038). NIMPIS (2002) states the species is introduced into Australia but shows it as cryptogenic throughout WA.

\section{Distribution elsewhere}

Cosmopolitan - Atlantic Ocean, West Africa from Mediterranean to Cape of Good Hope, East Mediterranean, Madagascar, Arabian Sea, Bay of Bengal, Indian Ocean, Thailand, Formosa, Sagami Bay, Japan, Malay Archipelago, East Indian Archipelago, New Zealand, Palau Island (Jones 1990b). In Australia from Bass Strait, Vic., lower east coast of NSW, north east coast of Qld. and Port Essington, NT (Jones et al. 1990; Furlani 1996).

\section{Remarks}

Megabalanus tintinnabulum is a cosmopolitan fouling species, first recorded in WA waters in 1949 (Jones 1990a, 1991, 1992a). The species is now known from southwestern to northwestern waters of WA (Hass and Jones 2000; Jones 1990a, 1990b; 1991, 1992b, 1999a, 2000, 2001a, 2004b, 2005; Jones and Hewitt 1997, 2001; Jones et al. 1990). Jones (1990) suggested that the species is an introduction via shipping, since most WA collection localities are in the vicinity of ports or areas that receive international shipping (e.g. Kwinana, Fremantle, Carnarvon, Barrow Island, Thevenard Island, Dampier, Cape Lambert, Cockatoo Island). Although early reports of $M$. tintinnabulum occurring on the eastern Australian coast may be erroneous (Allen 1953; Jones 1990a, 1991), records of the species have been confirmed from Bass Strait, Vic., and the lower, mid and north-eastern coasts and northern coast of Australia (Jones 1999b; Jones unpublished data; Jones et al. 1990). 


\section{Family Tetraclitidae}

Tesseropora rosea (Krauss, 1848)

Western Australian records and vouchers

Albany (WAM 18955); Cottesloe Beach (WAM 17763); Fremantle; Cockburn Sound (WAM 15963); Garden I. (Jones 1990c; WAM 536-86).

\section{Distribution elsewhere}

South Africa; Australasia - Australia, Lord Howe I., Kermadecs; in Australia, from eastern Australia between $19^{\circ}$ and $38^{\circ} \mathrm{S}$, Mallacoota, Inverloch, Vic. (Jones 1990a).

\section{Remarks}

Tesseropora rosea is a common intertidal species on the eastern Australian seaboard. Originally described from one specimen collected at Algoa Bay, South Africa (Krauss 1848), the species was subsequently recorded from NSW and Queensland (Darwin 1854), where it is abundant in exposed coastal areas in the intertidal (Jones et al. 1990). The species was not known from western areas of the continent until 1948 (Jones 1990a). In 1986, three live specimens were collected on intertidal granitic rock at Cottesloe and the species has also been found at Fremantle, Garden Island and Cockburn Sound and, more recently, Albany. The isolated occurences of this species, in the vicinity of active ports (Fremantle and Albany), led to the suggestion that the species had been introduced from eastern Australia via shipping. Since $T$. rosea is not known as a hull fouler, ballast water transport was implicated as the dispersal agent for the introduction of the species into the waters of Western Australia (Jones 1990c).

\section{Cnidaria}

\section{Class Hydrozoa (Hydroids)}

\section{Order Anthomedusae}

Family Corynidae

\section{Sarsia eximia (Allman, 1859) = Sarsia radiata von Lendenfeld, 1885}

\section{Western Australian records and vouchers}

Albany (WAM 30538); Houtman Abrolhos Is. (Watson 1996; Watson 1997); Shark Bay (Wyatt et al. 2005). NIMPIS (2002) shows this species as a known introduction to the south coast but cryptogenic on the lower west coast of WA.

\section{Distribution elsewhere}

Widespread, regarded as cryptogenic in the North Atlantic from North America to Europe and from
Iceland to France; Mediterranean; west coast of North America, Brazil, Valparaiso and the NW Pacific, New Zealand (Schuchert 1996); in Australia cosmopolitan and cryptogenic in Sydney Harbour, NSW, and numerous locations in Vic. (e.g., Bass Strait, Westernport Bay, Popes Eye Reef, as Sarsia radiata, Watson 1978, 1994, 1997, 1999); Port Phillip Bay, Vic. (Hewitt et al. 2004), introduced to Tas. (NIMPIS 2000).

\section{Family Eudendriidae}

\section{Eudendrium carneum Clarke, 1882}

Western Australian records and vouchers

Perth to Albany (Watson 1996); Bunbury (CRIMP, WAM 30531).

\section{Distribution elsewhere}

Circumtropical (Boero and Bouillon 1993); California; Ecuador; Mexico; California; north west Atlantic (Fraser 1948).

\section{Eudendrium cf. capillare Alder, 1856}

Western Australian records and vouchers Albany (WAM 30544).

\section{Distribution elsewhere}

Cosmopolitan (Fraser 1948; Boero and Bouillon 1993); in Australia from Qld. (Pennycuick 1959); Port Phillip Bay, Vic. (Ralph 1966).

\section{Family Tubulariidae}

Ectopleura crocea (Agassiz, 1862)

[including Tubularia crocea and Tubularia ralphi (Bale, 1884)].

Western Australian records and vouchers

Dunsborough (WAM 945); Cockburn Sound (WAM); Fremantle (Bock 1982; Watson 1999; CRIMP 2000). South coast and lower west coast of WA (NIMPIS 2002).

\section{Distribution elsewhere}

Native to Atlantic coast of North America, introduced to the Pacific coast of North America, Europe, Mediterranean, Japan, parts of Asia, Australia and New Zealand (Fraser 1948; Schuchert 1996; Watson 1999); in Australia from the east and south-east [e.g., Qld. (Pennycuick 1959); Port Phillip Bay, Vic. (Ralph 1966; Black 1971; Watson 1980; Hewitt et al. 2004); Sydney Harbour, Port Kembla, NSW (Watson 1980, 1999); Launceston, Tas. (Aquenol 2001)]. 


\section{Remarks}

This species forms colonies to $12 \mathrm{~cm}$ high composed of hundreds of greenish-white stems growing from a matted hydrorhiza (Watson 1999). It is a common fouling organism on the Victorian coast. This species was recorded on numerous occasions as Tubularia ralphii (Bale, 1884), the synonymy tentatively suggested by Schuchert (1996) and Watson (1999).

\section{Order Leptomedusae}

Family Aglaopheniidae

Aglaophenia parvula Bale, 1882

Western Australian records and vouchers Albany (WAM 30543).

Distribution elsewhere

Bass Strait, Vic. (Watson, 1994).

\section{Remarks}

Associated with sponges and ascidians (Watson 1994). The WA record of this cryptogenic species is based on a specimen in the WA Museum and requires verification.

\section{Gymnangium gracilicaule (Jäderholm, 1903)}

\section{Western Australian records and vouchers}

Houtman Abrolhos Is. (Watson 1996; Watson 1997); Port Hedland (CRIMP 1999; WAM 30557).

\section{Distribution elsewhere}

Widely distributed in the tropical and subtropical Indian Ocean and Indo-West Pacific (Watson, 1997).

\section{Family Campanulariidae}

\section{Obelia dichotoma (Linnaeus, 1758) (=Obelia australis)}

Western Australian records and vouchers

Albany (WAM 30546); Bunbury (WAM 30524); Shark Bay (Wyatt et al. 2005). South coast and lower west coast of WA (NIMPIS 2002).

\section{Distribution elsewhere}

Widespread in tropical and temperate waters of the Atlantic, Pacific, and Indian oceans (Fraser 1948; Calder 1991; Boero and Bouillon 1993; BrinckmannVoss 1996); in Australia from Qld. (Pennycuick 1959), Tas. and Bass Strait (Ralph 1957, Watson 1994, both as O. australis), Port Phillip Bay and Western Port, Vic. (Watson 1999) and Eden to Port Stephens, NSW (Allen and Wood 1950, as $O$. australis).

\section{Remarks}

Extremely opportunistic species growing in a wide variety of habitats including algal and invertebrate substrata, present in southern Australia at least since the 1880s (Watson 1999).

\section{Obelia longissima (Pallas, 1766)}

Western Australian records and vouchers Port Hedland (CRIMP 1999?; DALSE 2004).

Distribution elsewhere

Widespread (Fraser 1948; Ralph 1957; Boero and Bouillon 1993).

\section{Remarks}

According to comments on the NIMPIS web site (2002, under Obelia dichotoma: similar species), this species is not recorded for Australia, but, confusingly, elsewhere on the site it is listed as cryptogenic. The species is mentioned in the DALSE (2004) report as being recorded from Port Hedland by the CRIMP survey. In the CRIMP report, however, while the impacts of $O$. longissima are discussed (CRIMP 1999: 9), the species is not actually listed. Clarification of the Port Hedland record is clearly desirable.

\section{Family Haleciidae}

\section{Halecium delicatulum Coughtrey, 1876}

\section{Western Australian records and vouchers}

Albany (WAM 30536; 30545; 30549; 30546); Bunbury (WAM 30524); Houtman Abrolhos Is.; Perth to Albany (Watson 1996, 1997; WAM 30536; 30545; 30549). NIMPIS (2002) states that this species is introduced, but the map shows it occurring as cryptogenic on the south and lower west coasts.

\section{Distribution elsewhere}

Circumglobal tropical to Antarctic waters (Ralph 1958; Watson 1997); in Australia from numerous southern and eastern localities, e.g., Port Stephens, Port Jackson, and Coogee, NSW (Bale 1888; Ritchie 1911; Hodgson 1950; Bruny I., Tas. (Briggs 1914; Watson 1975); Port Phillip Bay, Western Port, and Bass Strait Vic. (Ralph 1966; Black 1971; Watson 1994; 1999; Hewitt et al. 2004); Qld. (Pennycuick 1959); Pearson Island, SA (Watson 1973).

\section{Remarks}

This is a common southern Australian species colonising many invertebrate and algal substrata (Watson 1997). 


\section{Family Halopterididae}

\section{Antennella secundaria (Gmelin, 1791)}

\section{Western Australian records and vouchers}

Cape Peron (WAM 2541); Perth to Albany, Houtman Abrolhos Is., Shark Bay to Exmouth (Watson 1996, 1997); Port Hedland (CRIMP 1999; WAM 30554; DALSE 2004). Introduced to the Pilbara and cryptogenic in the Kimberley and lower west coast of WA (NIMPIS 2002).

\section{Distribution elsewhere}

Cosmopolitan in temperate and tropical seas (Boero and Bouillon 1993; Watson 1997, 1999, 2000); in Australia from several southern and eastern localities, e.g., Qld. (Pennycuik 1959); Port Phillip Bay, Western Port, and Bass Strait, Vic. (Watson 1994, 1999; Hewitt et al. 2004); Pearson Island, SA (Watson 1973).

\section{Remarks}

Grows in thick masses on algal and invertebrate substrata in sheltered ocean waters, often amongst sponges and red algae (Bock 1982; Watson 1994).

\section{Family Plumulariidae}

\section{Plumularia setacea (Linnaeus, 1758)}

\section{Western Australian records and vouchers}

Cervantes (WAM 2650; 2629); Perth to Albany (Watson 1996); Jurien Bay (WAM 2632). NIMPIS (2002) states this is a known introduced species, but shows it as being cryptogenic on the south coast of WA.

\section{Distribution elsewhere}

Near cosmopolitan in subtropical and temperate seas (Fraser 1948; Boero and Bouillon 1993; Watson 1999, 2000); in Australia recorded from various southern and eastern localities, e.g., Port Phillip Bay and Bass Strait, Vic. (Bale 1888; Watson 1994, 1999); Tas. (Hodgson 1950); Qld. (Pennycuick 1959); Jervis Bay, NSW (Ritchie 1911).

\section{Remarks}

Generally found in sheltered, shallow waters, associated with algae, old shells and other invertebrates (Hodgson 1950; Bock 1982; Watson 1994), this species is reportedly intolerant of reduced salinity (Watson 1999).

\section{Plumularia warreni Stetchow, 1919}

\section{Western Australian records and vouchers}

Port Hedland (CRIMP 1999; WAM 30553).

\section{Distribution elsewhere}

South Africa, Madagascar, southwestern Indian Ocean (Gravier 1970; Gravier-Bonnet and Bourmaud 2006) and possibly Darwin (Watson pers. comm.).

\section{Remarks}

This species is listed for Port Hedland by CRIMP (1999) but without comment. The voucher specimen in WAM is listed as Plumularia cf. warreni and the identification requires confirmation (Watson 2007, pers. comm.).

\section{MOLLUSCA (Molluscs)}

\section{Class Gastropoda (Gastropods)}

Family Batillariidae

\section{Velacumantus australis (Quoy and Gaimard, 1834)}

\section{Western Australian records and vouchers}

Sandflats in lower Swan River and at Woodman Point, Cockburn Sound (Ewers 1967; Wells and Bryce 1986).

\section{Distribution elsewhere}

Queensland to South Australia; also Tasmania (Wells and Bryce 1986); northern NSW to southern Qld.

\section{Remarks}

Wells and Bryce (1986) state the WA records "May be the result of human introduction of the species" but there have been no further studies. The fossil record shows $V$. australis was previously more widespread across southern Australia but its range has since become more restricted. The record as an introduced species is tentatively accepted here.

Cotton (1984) also recorded $V$. australis from Albany, a record used by Ewers (1967) and Roberts and Wells (1980). However, the specimen was later determined to be a subfossil, and there are no records of living specimens from Albany (Wells 1984).

\section{Family Cymatiidae}

Cymatium cutaceum africanum (A. Adams, 1854)

Western Australian records and vouchers

Augusta (Wells and Kilburn 1986; WAM 54-82).

\section{Distribution elsewhere}

South Africa (Wells and Kilburn 1986).

Remarks

A single specimen of this species was collected at 
Augusta by W. Anson on 27 or 28 January 1979. The species may well have arrived naturally in Western Australia as Augusta is not a major shipping area. This was apparently an isolated individual, and despite searching of the area no known populations exist in Augusta. In its natural range, this species lives among solitary ascidians offshore, under rocks at low tide or on sand near ascidians (Wells and Kilburn 1986).

\section{Family Facelinidae}

\section{Godiva quadricolor (Barnard, 1927)}

Western Australian records and vouchers

Found in Cockburn Sound and Fremantle in 1980, 1983 and 1997 (Willan 1987b; WAM 339-86; 26849). South coast and lower west coast of WA (NIMPIS 2002).

\section{Distribution elsewhere}

Native to South Africa, from the Cape of Good Hope to Port Alfred (Willan 1987b), introduced to Port Jackson, NSW (Macnae 1954, as Hervia quadricolor).

\section{Remarks}

The specimen was collected by C. Bryce at the southern end of Cockburn Sound on 10 January 1984 and photographed. Detailed notes on the find were reported by Willan (1987b) and subsequently repeated by Furlani (1996). An experienced amateur photographer, G. Saueracker also saw specimens in the Fremantle to Cockburn Sound area at about the same time (Willan, 1987b). The species is also recorded by Fisheries WA (2000) and NIMPIS (2002).

\section{Family Goniodorididae \\ Okenia pellucida Burn, 1967}

Western Australian records and vouchers

Fremantle (Willan and Coleman 1984, no vouchers in WAM).

\section{Distribution elsewhere}

Widespread (see remarks); native range unknown but possibly includes Sydney, NSW (Willan and Coleman 1984).

\section{Remarks}

Rudman (2004) reported that this species, which was described from Sydney, is widespread, and has been reported from Hawaii, Japan, Palmyra Atoll, Malaysia, and the United Arab Emirates, in addition to Australia (NSW, Qld., WA). The species lives and feeds on the bryozoan Zoobotryon verticillatum. This is a common fouling species that is believed to be moved readily by shipping activities.

\section{Family Haliotidae}

\section{Haliotis spadicea Donovan, 1808}

Western Australian records and vouchers Cowaramup Bay, south of Cape Naturaliste, 1952, referring to $H$. sanguinea (Macpherson 1953; MV F12987)

Distribution elsewhere

Native to South Africa (Macpherson 1953).

\section{Remarks}

Like the three species reported from Augusta by Wells and Kilburn (1986), this is a record of a South African species that may have arrived in Western Australia naturally. No populations have been subsequently recorded and the identification of the specimen needs to be checked.

\section{Haliotis diversicolor Reeve, 1846}

Western Australian records and vouchers Not present; no vouchers.

Distribution elsewhere Japan and China.

\section{Remarks}

Geiger (2000) and Geiger and Poppe (2000) show localities of North West Cape and Albany, but this is in error because the extensive collections in WAM do not record a single specimen of this species from WA.

\section{Haliotis hargravesi (Cox, 1869)}

Western Australian records and vouchers Not present; no vouchers.

\section{Distribution elsewhere}

Northern NSW to southern Qld.

\section{Remarks}

Geiger and Poppe (2000) show a locality of Carnarvon with a question mark. This locality is incorrect because the extensive abalone holdings in WAM do not record a single specimen of this species in WA

Family Nassariidae

Bullia annulata Lamarck, 1816 
Western Australian records and vouchers

Augusta (Wells and Kilburn 1986; WAM 52-82; Furlani 1996).

\section{Distribution elsewhere}

South Africa (Wells and Kilburn 1986; Furlani 1996).

\section{Remarks}

A single specimen of this species was collected at Flinders Bay, Augusta, by W. Anson on an unknown date. The species may well have arrived naturally in Western Australia as Augusta is not a major shipping area. This was apparently an isolated individual, and despite searching of the area no known populations exist in Augusta.

\section{Nassarius burchardi (Dunker in Philippi, 1849)}

Western Australian records and vouchers

Southern Qld. to Fremantle, WA; Swan River, 1965 (Chalmer et al. 1976; Slack-Smith and Brearley 1987). There are numerous specimens in WAM from a variety of WA locations.

\section{Distribution elsewhere}

Southern Australia.

\section{Remarks}

This species was first recorded in the Swan River in 1965 (Wilson and Kendrick 1968; Chalmer et al. 1976; Slack-Smith and Brearley 1987). However, it was simply an extension of the species into the estuary, and not an introduction. The species has been reported from a wide range of localities from across southern WA to the Swan River by Wells (1984), Wells and Bryce (1986) and Wilson (1994). The ecology of N. burchardi was investigated by Kowarsky (1969) and Smith (1975).

\section{Nassarius kraussianus (Dunker, 1846)}

Western Australian records and vouchers

Augusta (Wells and Kilburn 1986; WAM 51-82; 2670-83; 2670-83; 51-82).

\section{Distribution elsewhere}

South Africa (Wells and Kilburn 1986).

\section{Remarks}

Two shells of this species were collected at Augusta by Wendy Anson in January 1974 and by Glad Hansen at Flinders Bay, Augusta, on 2 July 1972. The species may well have arrived naturally in Western Australia as Augusta is not a major shipping area. These were apparently isolated individuals, and despite searching of the area no known populations exist in Augusta.

$$
\text { Family Polyceridae }
$$

$$
\text { Polycera hedgpethi Marcus, } 1964
$$

Western Australian records and vouchers

Quaranup, Princess Royal Harbour (Wells and Bryce 1993; Furlani 1996; NIMPIS 2002); Rockingham (WAM 29806). Lower west coast of WA (NIMPIS 2002).

\section{Distribution elsewhere}

California; Caribbean; Mediterranean; South Africa; New Zealand; Japan; Iberian Peninsula (Gosliner 1982; Pollard and Hutchings 1990b; Gofas and Zenetos 2003); in Australia from NSW, Vic., SA (Hutchings et al. 1987; Furlani 1996), e.g., Port Phillip Bay and Mallacoota, Vic. (Willan and Coleman 1984; Hewitt et al. 2004) and Port Hacking, NSW (Willan and Coleman 1984).

\section{Remarks}

This species was thought to be an introduction from California, where it was originally described. However, the natural range is obscure (Wilson 2006). Specimens were known from New Zealand prior to the original species description (Miller 2001) and the species was recorded in Australia only nine years later. In Western Australia the species was originally recorded from jetty pilings at Quaranup, Princess Royal Harbour at Albany in February 1980 (Wells and Bryce 1993: 76). Wilson (2006: 138) stated that no further specimens have been recorded from that locality or for the entire State (based on a pers. comm. C. Whisson and C. Bryce of the WA Museum), but the species has subsequently been collected from Rockingham in 2005 (WAM 29806).

\section{Class Bivalvia (Bivalves)}

Order Myoida

\section{Family Teredinidae (Shipworms)}

Western Australian records and vouchers

Various, see Brearley et al. (2003) for vouchers.

\section{Distribution elsewhere \\ Variable.}

\section{Remarks}

Shipworms get their common name from their habit of boring into the wood of early ships, but they are actually bivalve molluscs. They also burrow into mangroves, with some species 
occurring in live wood, others in dead wood and some in both. The species also colonise dead logs. This habitat has resulted in many species of shipworms occupying widespread ranges and being introduced into a variety of different coastal areas, but it is very difficult to determine what the original distribution was for each species. Turner (1966, 1971a, 1971b) and Marshall and Turner (1974) provide information on species occurring in Australia, including Western Australia. Brearley et al. (2003) studied the distribution of five species of teredinids and one pholad in mangroves at the Burrup Peninsula near Dampier, and provide a table showing the locations where 28 species have been recorded in Australia. Teredo navalis Linnaeus, 1758 is shown by NIMPIS (2002) to occur from the south coast to Kalbarri. However, despite all of these studies, we do not know what species were native to WA and which have been introduced. Until further information is obtained, the record is excluded.

\section{Order Mytiloida}

Family Mytilidae

\section{Musculista senhousia (Benson in Cantor, 1842)}

\section{Western Australian records and vouchers}

This species was first found at Chidley Point in the Swan River estuary in 1983. Subsequent sampling in 1984 revealed that it was as far upstream as the Canning Bridge and Perth Water. It has also been recorded in Fremantle (SlackSmith and Brearley 1987; Willan 1985a, 1985b, 1987a; Hutchings et al. 1987; Pollard and Hutchings 1990b; Furlani 1996; Wilson 1998; Fisheries WA 2000; CRIMP 2000; WAM 10748, $12718,14305,16462,16910)$. Lower west coast of WA (NIMPIS 2002).

\section{Distribution elsewhere}

Native to Pacific coast of Asia. This is an invasive species that has been recorded in a wide variety of areas, including the Mediterranean, USA, India, and New Zealand. In Australia it occurs in Port Phillip Bay, Vic., Devonport, Launceston and the Tamar River, Tas., St Kilda, SA (Willan 1985a, 1985b, 1987a; Hutchings et al. 1987; Pollard and Hutchings 1990b; Coleman 1993; Furlani 1996; Aquenol 2001; Hewitt et al. 2004; NIMPIS 2002).

\section{Remarks}

Although the species was common in the lower Swan River in the 1980s, recent attempts to find specimens for DNA analysis have not recorded any individuals. A survey to determine the present distribution of $M$. senhousia is planned for late 2007.
Mytilus edulis planulatus Lamarck, 1819

\section{Western Australian records and vouchers}

WA as far north as Cockburn Sound (see remarks below). Numerous specimens in the WAM, including N4017, N4172, 514-40, all from Albany; 141-66 Wilson Inlet; 77-63 Bunbury; N1650 Garden Island.

\section{Distribution elsewhere \\ Western Europe, Mediterranean.}

\section{Remarks}

The taxonomy of this species is confused. It is used for aquaculture in the Albany harbours, Warnbro Sound and Cockburn Sound, WA, under the name $M$. edulis. Shepherd and Thomas (1989) state that blue mussels were collected in King George Sound by François Péron on the French corvette Géographe and were later described as Mytilus planulatus Lamarck, which is now considered to be a subspecies of $M$. edulis.

Furlani (1996) and NIMPIS (2002) use the name M. galloprovincialis Lamarck and give an inferred distribution throughout Western Australia as far north as North West Cape. In fact, blue mussels are found in protected bays and estuaries only as far north as Cockburn Sound (Wells 1984). Furlani (1996) and NIMPIS (2002) state that the two species are inseparable on shell characteristics but can be separated genetically (Geller et al. 1993). More recently, Coghlan and Gosling (2007) investigated the two species in Ireland and showed that they cooccur, with a large proportion of the populations (greater than $33 \%$ ) being hybrids. There were more $M$. galloprovincialis on open shores than in protected bays. Such genetic work has not been undertaken in Western Australia.

In a volume on Quaternary molluscs of South Australia, Ludbrook (1984) describes M. edulis planulatus living in SA. However, in other chapters she reports the mussels Brachidontes cf. suberosus (Singleton) from the Pleistocene and Brachidontes erosus (Lamarck 1819) and B. rostratus (Dunker 1857) from the Holocene of SA, but not $M$. edulis planulatus. The origins of the Australian form of this species remain uncertain. It may also be an introduction dating to the $16^{\text {th }}$ century (Hewitt 2003).

\section{Order Ostreoida}

\section{Family Ostreidae}

\section{Crassostrea gigas (Thunberg, 1793)}

\section{Western Australian records and vouchers}

Not present, although the species is recorded for WA localities in several publications, e.g., Albany, 1947 (Thomson 1952; Fisheries WA 2000); specific 
location not specified (Coleman and Hickman 1986); WA (Pollard and Hutchings 1990b). No vouchers. NIMPIS (2002) originally had this species as introduced to the south coast of WA, but currently shows a blank in this area.

\section{Distribution elsewhere}

Native to the north-west Pacific, introduced widely in temperate to tropical seas for aquaculture (Dinamani 1971; Zibrowius 1991; Gofas and Zenetos 2003); in Australia introduced to several locations, e.g., southern and northern Tas. (Thomson 1952, 1954; Aquenol 2001), Port Phillip Bay, Vic. (Hewitt et al. 2004), Mallacoota Inlet, Vic., Anderson Inlet, NSW (Coleman and Hickman 1986).

\section{Remarks}

Also known as the Pacific oyster, this species was introduced for aquaculture into Tasmania and Oyster Harbour, Western Australia in 1947. However, the specimens were shipped from Japan by boat and took too long to arrive in Australia. Mortality was very high, and the experiment was unsuccessful. A subsequent attempt was made successfully to ship broodstock by air to Tasmania. The species has since spread to Vic., NSW and SA. It is unusual in being considered to be both a pest species and a valuable species for aquaculture. The history of the introduction is detailed in a number of reports (Thomson 1952, 1959; Sumner 1972, 1974; Medcof and Wolf 1975; Coleman 1986; Coleman and Hickman 1986; Hutchings et al. 1987; Furlani 1996; Fisheries WA 2000). Victoria has banned its use as an aquaculture species since 1996 (T. O'Hara, pers. comm.).

Thomson (1959) clearly states the attempt to introduce the species into Oyster Harbour was unsuccessful. In a study of the molluscs of the Albany area, Roberts and Wells (1980) did not record C. gigas. A similar study of the Esperance area also failed to disclose any material (Wells et al., 2005). Furlani (1996) reports the deliberate introduction of $C$. gigas into Oyster Harbour but fails to mention that the introduction was not successful. She records the species on the basis of a dead shell taken from Cockburn Sound, and provides a presumed distribution of the species from the entire coastline between Onslow, WA, through to northern NSW. However, $C$. gigas is occasionally imported into WA for restaurants, and it is possible that was the source of the Cockburn Sound shell. The original NIMPIS database included this distribution (e.g., see list of 'known exotic species in Australian waters' in CRIMP 2000: 17), but following approaches to the Centre for Research into Introduced Marine Pests, it has been removed. There are no verified records of the species in WA.

\section{Ostrea edulis (Linnaeus, 1758)}

\section{Western Australian records and vouchers}

Oyster Harbour, Albany (Morton et al. 2003).

\section{Distribution elsewhere \\ Native to Western Europe.}

\section{Remarks}

Morton et al. (2003) discuss this species in detail. While there had been literature uses of the name Ostrea edulis for southern localities, recent authors used the name $O$. angasi (Sowerby, 1871). This is the species for which Oyster Harbour was named by Vancouver in 1798. Morton et al. (2003) examined DNA sequences of ten individuals from Oyster Harbour; seven were $O$. angasi and three were $O$. edulis. Once the species were determined genetically, differences in the species were found in the shells. The authors speculate that $O$. edulis could have been introduced into Australia either accidentally or unofficially, but do not report on when this may have occurred.

\section{Family Pectinidae}

\section{Scaeochlamys livida (Lamarck, 1819)}

\section{Western Australian records and vouchers}

Fremantle Harbour and Cockburn Sound (CRIMP 2000, as Chlamys livida; WAM S14964).

\section{Distribution elsewhere \\ Eastern Australia.}

\section{Remarks}

This scallop species was recorded in the CRIMP (2000) survey of Fremantle Harbour and Cockburn Sound. It did not attract attention in the survey because it is introduced from eastern Australia and not overseas. Morrison and Wells (2008) provide full details on the species in Fremantle Harbour and Cockburn Sound. It first appeared about 1985 and is now well established.

\section{Order Veneroida}

Family Mactridae

\section{Spisula trigonella (Lamarck, 1818)}

\section{Western Australian records and vouchers}

Shark Bay, Swan River, Garden Island, Peel Inlet, Nornalup Inlet (Wilson and Kendrick 1968); Swan River (Chalmer et al. 1976). Numerous specimens in WAM including WAM 581-67; 582-67; 580-67. 
Distribution elsewhere

Eastern Australia, widespread in Qld., NSW, Tas., Vic., and SA (Wilson and Kendrick 1968).

\section{Remarks}

This species appeared suddenly in the Swan Estuary about 1964, as documented by Wilson and Kendrick (1968). Chalmer et al. (1976) reported that by the mid 1970s it had become a conspicuous inhabitant of the lower and middle Swan Estuary. They also reported that marine records are rare in WA. However, the species appears to be native to the state, and has been recorded from a number of southwestern estuaries (Wells 1984).

\section{Family Semelidae}

\section{Theora lubrica Gould, 1861}

\section{Western Australian records and vouchers}

Bunbury (CRIMP 1997a); Rockingham, Swan River (Chalmer et al. 1976; Slack-Smith and Brearley 1987; Hutchings et al. 1987; Pollard and Hutchings 1990b; Furlani 1996). Voucher from Lucky Bay, ca. $600 \mathrm{~m}$ north of Pt Waylen, Swan estuary. Lower west coast of WA (NIMPIS 2002).

\section{Distribution elsewhere}

Pacific coast of Asia, California, New Zealand (Chalmer et al. 1976; Pollard and Hutchings 1990b), in Australia introduced to Port Phillip Bay, Vic. (Coleman 1993; Furlani 1996, as Theora fragilis; Hewitt et al. 2004) and Launceston, Tas. (Aquenol 2001).

\section{Remarks}

Coleman (1993) records Musculista senhousia and Theora lubrica from Corio Bay, Port of Geelong, where T. Iubrica is an abundant species. Both were introduced from the east coast of Asia. Theora Iubrica arrived at least in the early 1970s and was identified as T. fragilis A. Adams (Poore and Rainer 1974; Hutchings et al. 1987; Pollard and Hutchings 1990b). The taxonomy of this species appears to be confused. Furlani (1996) and NIMPIS (2002) use $T$. lubrica, but state that $T$. fragilis may be an earlier, valid name.

The WA material, based on a single record, needs confirmation of the identification.

\section{Annelida}

\section{Class Polychaeta (Polychaetes)}

\section{Order Phyllodocida}

Family Nereididae
Alitta succinea (Leuckart, 1847)

$=$ Neanthes oxypoda Marenzeller, 1879, Nereis oxypoda Marenzeller, 1879, Neanthes succinea Hartman, 1938

\section{Western Australian records and vouchers}

Swan River, 1938 as Neanthes oxypoda (Monroe, 1938); Swan River, 1946 as Nereis oxypoda (Thomson, 1946); Swan River as Neanthes succinea (Wilson, 1984). Lower west coast and south coast of WA (NIMPIS 2002). No vouchers in WAM.

\section{Distribution elsewhere}

Widely distributed in both hemispheres (Wilson 1988); in Australia from Yarra River, Maribyrnong River, and Port Phillip Bay, Vic. (Wilson 1984; Cohen et al. 2001; Hewitt et al. 2004) and (as Neanthes oxypoda): Port Hacking, Hawkesbury River, Lake Macquarie, NSW (Hutchings and Murray 1984; Wilson 1999).

\section{Remarks}

All Australian records of this species are from estuaries associated with or adjacent to major shipping harbours (Wilson 1999). According to Wilson (1984), published records of Neanthes oxypoda from Australia, China and Japan confuse two distinct forms, with material from China and Japan probably being an undescribed species. More recent records are likely to be the result of introductions by humans, both intentional and accidental (Wilson 1988).

\section{Order Sabellida}

$$
\text { Family Sabellidae }
$$

\section{Sabella spallanzanii (Gmelin, 1791)}

\section{Western Australian records and vouchers}

Esperance (Clapin pers. comm., cited in CRIMP, 2000; WAM 4612; Campbell 2003b; WAM 4617; 4618); Albany (CRIMP 1997b; WAM 4048); Bunbury (WAM 4054; 4056; CRIMP 1997a; WAM 7283; 7285); Cockburn Sound, Fremantle (Clapin and Evans 1995; CRIMP 2000; WAM 4613; 4053). South coast and lower west coast of WA (NIMPIS 2002).

\section{Distribution elsewhere}

Native to the Mediterranean and Atlantic east coast to English Channel, introduced to South-East Asia, Rio de Janeiro and various localities in temperate Australia (West Lakes, North Haven, and Port River, SA, Port Phillip Bay, Vic., Devonport, Tas., and Twofold Bay, NSW) (Carey and Watson 1992; Clapin and Evans 1995; Furlani 1996; Currie et al. 1998, 2000; CRIMP 2000; Cohen et al. 2001; Pollard and Rankin 2003; Hewitt et al. 2004). 


\section{Remarks}

Also known as the European fan worm, this species was first noted in south-west Western Australia in 1994-5 (Clapin and Evans 1995), but specimens from Albany in the WA Museum date from 1965, 1978 and 1979. The species was first observed in Cockburn Sound in 1994.

\section{Myxicola infundibulum (Renier, 1804)}

\section{Western Australian records and vouchers}

NIMPIS (2002) states the species is introduced to Australia but shows it as cryptogenic on the south coast and lower west coast of WA. No vouchers in WAM.

\section{Distribution elsewhere}

In Australia, from Port Phillip Bay, Port of Melbourne, Geelong and Portland, Vic. (Black 1971; Knox and Cameron 1971; Parry et al. 1997; Currie et al. 1998; Cohen et al. 2001; Hewitt et al. 2004); Hong Kong (Paxton and Chou 2000).

\section{Remarks}

The identity of Australian records currently known as Myxicola infundibulum are currently being investigated by $\mathrm{E}$. Dane and $\mathrm{R}$. Wilson at Museum Victoria (T. O’Hara, pers. comm.).

\section{Family Serpulidae}

Hydroides elegans Haswell, 1883

[also reported as Hydroides norvegica Gunnerus]

Western Australian records and vouchers

Cockburn Sound, 1978 (Lewis 1982). No vouchers in WAM.

\section{Distribution elsewhere}

Native distribution unknown, but appears to be of tropical/subtropical origin. Also known in the Mediterranean, Hawaii, Hong Kong, China, New Zealand and various locations in Australia, e.g., Port Phillip Bay, Vic., Port Jackson, NSW, and Qld. (Allen 1953; Wisely 1958; Hurlbut 1991; Zibrowius 1991; Paxton and Chou 2000; Hewitt et al. 2004).

\section{Remarks}

Often incorrectly identified in early Australian records as Hydroides norvegica (NIMPIS 2002) which $H$. elegans was considered synonymous with. Recognition of morphological differences between the two species (Zibrowius 1991) has shown $H$. norvegicus to be restricted to the Atlantic and Mediterranean, with $H$. elegans a widespread fouling species common in temperate southern
Australia (Lewis et al. 2006). This species is regarded as a considerable fouling nuisance (Lewis et al. 2006).

\section{Ficopomatus enigmatica (Fauvel, 1923)}

\section{Western Australian records and vouchers}

Peel - Harvey Estuary (WAM 86); Swan River (Monroe 1938; Allen 1953; Hove and Weerdenburg 1978; Hutchings and Murray 1984; Hutchings et al. 1987; Pollard and Hutchings 1990b).

\section{Distribution elsewhere}

Native distribution unknown, but appears to be of subtropical or temperate origin. Also known in the Mediterranean, U.K., France, Spain, India, Egypt, Tunisia, Black Sea, Japan, North and South America and various locations in Australia (SA, Port Phillip Bay, Vic., Sydney, NSW, Qld.) (Monroe 1938; Allen 1953; Hove and Weerdenburg 1978; Hutchings and Murray 1984; Hutchings et al. 1987; Pollard and Hutchings 1990b; Zibrowius 1991; Cohen et al. 2001; Hewitt et al. 2004).

\section{Remarks}

Prevously known as Mercierella enigmatica Fauvel. Hove and Weerdenburg (1978) state that many records in the literature are based on incorrectly identified material. Tolerant of salinity fluctuations (Allen 1953).

\section{Order Spionida}

$$
\text { Family Spionidae }
$$

\section{Boccardia proboscidea Hartman, 1940}

\section{Western Australian records and vouchers}

Fremantle (Hartmann-Schröder 1982; Hutchings et al. 1987; Pollard and Hutchings 1990b; Furlani 1996). Lower west coast of WA (NIMPIS 2002). No vouchers in WAM.

\section{Distribution elsewhere}

Native to Japan or north-eastern Pacific; also found in Chile, Panama and locations in temperate Australia, e.g., Eyre Peninsula, SA, Port Phillip Bay and several locations to Portland, Vic., and Lake Macquarie, NSW (Blake and Kudenov 1978; Hartmann-Schröder 1982; Carlton 1985; Hutchings et al. 1987; Hartmann-Schröder 1989; Pollard and Hutchings 1990b; Furlani 1996; Wilson 1999; Cohen et al. 2001; Hewitt et al. 2004).

\section{Remarks}

This species was first noted in Fremantle Harbour in 1975 and was probably introduced through ballast water or hull fouling (Hartmann-Schröder 1982). 


\section{Polydora ciliata Johnston, 1938}

Western Australian records and vouchers

Fremantle, Cockburn Sound (Day 1975; Hutchings et al. 1987; Pollard and Hutchings 1990b; WAM 128).

\section{Distribution elsewhere}

Native to the Atlantic, Mediterranean, also found in the Indo-West Pacific, introduced to Newcastle, NSW (Haswell 1885; Day 1975; Pollard and Hutchings 1990b). NIMPIS (2002) shows this species as a known introduction to the Pilbara but cryptogenic on the lower west coast.

\section{Remarks}

Possibly a misidentification, the single Western Australian specimen (collected in 1972) was identified only from the anterior half as the posterior half was missing (Day 1975). Hutchings et al. (1987) echoes these sentiments and Furlani (1996) treats this as an unconfirmed record.

\section{Pseudopolydora paucibranchiata (Okudu, 1937)}

Western Australian records and vouchers

WA, 1979 (Hutchings et al. 1987 citing HartmanSchroder 1981 WA (Pollard and Hutchings 1990b). No vouchers in WAM

\section{Distribution elsewhere}

Native to the north-west Pacific; introduced to west coast of USA, France, New Zealand (Blake and Kudenov 1978); in Australia recorded from the south-east, e.g., Botany Bay, Port Hacking, Jervis Bay, Merimbula, NSW, Port Phillip Bay, Westernport Bay, Vic., Porter Bay, Torrens Island, Port Lincoln, SA (Dorsey 1982; Hutchings and Turvey 1984; Hutchings and Murray 1984; Carlton 1985; Pollard and Hutchings 1990b; Wilson 1999; Hewitt et al. 2004).

\section{Remarks}

This species is only presumed to occur in WA according to Furlani (1996) and is not recorded for the state by NIMPIS (2002).

\section{Chordata}

\section{Class Ascideacea (Ascidians)}

\section{Order Phlebobranchia}

$$
\text { Family Ascidiidae }
$$

\section{Ascidiella aspersa (Mueller, 1776)}

Western Australian records and vouchers

Esperance (WAM 30936); Albany (Kott, 1985;
CRIMP 1997b); Bunbury (CRIMP 1997a); Fremantle (CRIMP 2000) Bunbury; Pt Walter, Swan R. (George and George 1979; Kott 1985; Furlani 1996); Swan River (CRIMP; WAM 30507). South coast and lower west coast and Pilbara of WA (NIMPIS 2002).

\section{Distribution elsewhere}

Native to the Mediterranean, introduced to the eastern Atlantic and east coast of USA, New Zealand and temperate Australian waters (various isolated estuaries and bays from the Swan River, W.A., to SA, Tas. and Vic.) (Black 1971; George and George 1979; Kott 1985; Furlani 1996; Currie et al. 1998; Keough and Ross 1999; Cohen et al. 2001; Hewitt et al. 2004).

\section{Remarks}

First seen in Albany in 1952 and subsequently in the Swan River in 1962. Found on rocks and other surfaces in the inter-tidal zone to depths of $50 \mathrm{~m}$ or more (George and George 1979).

\section{Family Cionidae \\ Ciona intestinalis (Linnaeus, 1767)}

\section{Western Australian records and vouchers}

Esperance (Western Australian Museum 2002; Campbell 2003b; McDonald 2004; WAM 30565); Albany (WAM 744-83); Bunbury (CRIMP 1997a); Canning R.; Albany, Fremantle, Swan R. (Kott 1985, 1990; Furlani 1996; CRIMP 1997b, 2000; WAM 30765). South coast and lower west coast of WA (NIMPIS 2002).

\section{Distribution elsewhere}

Native to the North Atlantic, introduced to North and South America; Hong Kong; China Sea; Indonesia; New Zealand; most harbours throughout the world and ports throughout Australia (Port Adelaide and Adelaide outer harbour, SA, Portland and Port Phillip Bay, Vic., Derwent Estuary, Tas., Port Jackson and Newcastle, NSW, Rockhampton, Qld) (Herdman 1899; Van Name 1945; Allen and Wood 1950; Black 1971; Kott 1990, 1997; Furlani 1996; Currie et al. 1998; Keough and Ross 1999; CRIMP 2000; Cohen et al. 2001; Hewitt et al. 2004).

\section{Remarks}

Kott (1997) suggests that $C$. intestinalis appears to be declining in many of the locations in which it was once common, and the report of this species in Bandy Creek Harbour, Esperance, is the first to be published for almost ten years (McDonald 2004: 869). The species was recorded for Fremantle by CRIMP (2000). Ciona intestinalis 
is known to rapidly cover the substratum, smothering the existing species (Lambert and Lambert 1998, cited in McDonald 2004). Surveys of the Bandy Creek harbour following severe local flooding and sedimentation in early 2007 indicate that this might have eradicated the population in that small harbour (Travers, pers. comm.)

\section{Order Stolidobranchia}

Family Styelidae

\section{Botrylloides leachi (Savigny, 1816)}

\section{Western Australian records and vouchers}

Esperance (Western Australian Museum, 2002; Campbell, 2003b; WAM 30564); Albany (CRIMP, 1997b; WAM 16463); Bunbury (CRIMP, 1997a); Shark Bay (Wyatt et al. 2005); Barrow I. (Western Australian Museum 2005; WAM 29711); Geraldton, Fremantle, Rottnest I., Cockburn Sound, Bunbury, Busselton, Albany-Princess Royal Harbour (all collected in 1905) (Hartmeyer and Michaelsen 1928); Geraldton, Cockburn Sound, Bunbury, Albany, Dampier Archipelago, Rowley Shoals, Port Gregory, Houtman Abrolhos, Cockburn Sound (Kott 1985). North Mole, Fremantle (WAM 9583; 9584). Introduced into all areas of WA (NIMPIS 2002).

\section{Distribution elsewhere}

Northeastern Atlantic, Europe, British Isles, North Sea, western Mediterranean, Adriatic Sea, Black Sea, Indonesia, western Indian Ocean, Red Sea, South Africa, New Zealand, Australia wide (Herdman 1899; Kott 1985; Furlani 1996; Cohen et al. 2001; Aquenol 2001; Hewitt et al. 2004).

\section{Botryllus schlosseri (Pallas, 1766)}

\section{Western Australian records and vouchers}

Esperance (WAM 30562); Albany, Cockburn Sound, Swan River, Shark Bay, Rowley Shoals (Hartmeyer and Michaelsen 1928; Kott 1985; Sabbadin and Graziani 1967; Furlani 1996). WAM 945-6.83, 963.83, 929.83, 938.83. Introduced into all areas of WA (NIMPIS 2002).

\section{Distribution elsewhere}

Native to the north-east Atlantic to Mediterranean, Adriatic Sea and Black Sea; introduced to North America, Hong Kong, Japan, New Zealand, and Australia-wide with the apparent exception of NSW (Kott 1985; Furlani 1996; Cohen et al. 2001; Hewitt et al. 2004).

\section{Styela plicata (Lesueur, 1823)}

\section{Western Australian records and vouchers}

Bunbury (CRIMP 1997a); Monte Bello Is., Swan River, Canning River, Cockburn Sound, Bunbury (Kott 1952, 1985; Hutchings et al. 1987; Pollard and Hutchings 1990b; Furlani 1996). Shark Bay (Wyatt et al. 2005); Esperance (Western Australian Museum 2002; Campbell 2003b; WAM 30561). West coast and Pilbara of WA (NIMPIS 2002).

\section{Distribution elsewhere}

Native range unknown, cryptogenic in various widespread locations in the Mediterrranean and warmer parts the Pacific, Indian and Atlantic Oceans, introduced to Atlantic South America and probably Australia-wide (Allen and Wood 1950; Kott 1952, 1985; Hutchings et al. 1986, 1987, 1989; Pollard and Hutchings 1990b; Furlani 1996; Currie et al. 1998; Cohen et al. 2001; Hewitt et al. 2004).

\section{Remarks}

First local specimens came from Cockburn Sound in 1928.

\section{Styela clava (Herdman, 1881)}

Western Australian records and vouchers

Albany, Cockburn Sound (Kott 1985). No vouchers in WAM.

\section{Distribution elsewhere}

Native to the northwest Pacific: Japan, Korea, Northern China, and Siberia; spread to parts of northwestern Europe, North America. In Australia from northern Tas., southern NSW, and Port Phillip Bay, Vic. (Kott 1985; Pollard and Hutchings 1990b; Currie et al. 1998; Cohen et al. 2001; Hewitt et al. 2004).

\section{Remarks}

This species was recorded for WA by Kott (1985) but a western distribution is not indicated by NIMPIS (2002).

\section{Class Actinopterygii (Fish)}

Order Perciformes

Family Gobiidae

\section{Acentrogobius pflaumii (Bleeker, 1853)}

Western Australian records and vouchers

Swan River; Cockburn Sound (B. Hutchins, pers comm.).

Distribution elsewhere

Native to the north-west Pacific: Japan, Korea, 
China, Philippines; introduced to New Zealand; in Australia from Port Phillip Bay, Vic. (Lockett and Gomon 1999, 2001; Cohen et al. 2001; Hewitt et al. 2004).

\section{Remarks}

In Port Phillip Bay, this species is common on soft sediments around pier pylons in water deeper than $5 \mathrm{~m}$ (Lockett and Gomon 1999, 2001).

\section{Tridentiger trigonocephalus (Gill, 1858)}

\section{Western Australian records and vouchers}

Bunbury (CRIMP 1997a; WAM 32763); Swan River, Fremantle Harbour, Cockburn Sound (Chubb et al. 1979; Bodeker 1985; Paxton and Hoese 1985; Pollard and Hutchings 1990a; Gomon et al. 1994; Lockett and Gomon 1999, 2001; CRIMP 2000). Swan River (WAM 26037; 27679; 27690); Cockburn Sound (WAM 25945). South coast and lower west coast of WA (NIMPIS 2002).

\section{Distribution elsewhere}

Native to north-west Pacific (Japan, China, Korea), introduced to California and parts of Australia, e.g., Sydney Harbour and Port Kembla, NSW; Port Phillip Bay, Vic. (Friese 1973; Hoese 1973; Bodeker 1985; Paxton and Hoese 1985; Hutchings et al. 1987; Pollard and Hutchings 1990a; Gomon et al. 1994; Furlani 1996; Lockett and Gomon 1999, 2001; Cohen et al. 2001; Hewitt et al. 2004).

\section{Remarks}

In eastern Australia (Sydney Harbour and Port Phillip Bay), this species occurs among seagrass and is associated with a variety of substrata; it is common around commercial port regions (Pollard and Hutchings 1990a; Lockett and Gomon 2001).

\section{Family Sparidae}

\section{Sparidentex hasta Valenciennes, 1830}

\section{Western Australian records and vouchers}

Swan River, 1985 (Bodeker 1985; Harvey and Beard 1985; Anon. 1985; Hutchings et al. 1987; Pollard and Hutchings 1990a; WAM 28437).

\section{Distribution elsewhere}

Arabian Sea, west coast of India, Persian Gulf (Pollard and Hutchings 1990a).

\section{ACKNOWLEDGEMENTS}

In cooperation with several other agencies, the Department of Fisheries started a project Actions to implement and complement the national system for the prevention and management of introduced marine pests in Western Australia in October 2006. The present publication is part of the project, which is funded by the Australian Government's Natural Heritage Trust, delivered in Western Australia in partnership with the State government. This component was funded through the W.A. Strategic Reserve fund (project no. 053085). We also thank Dr Pat Hutchings (Australian Museum) and Dr Tim O'Hara (Museum Victoria) for comments on the entire manuscript, Dr Barry Hutchins and Sue Morrison (WA Museum) for comments on fish species, Clay Bryce, Corey Whisson and Shirley Slack-Smith for comments on molluscs, Dr Josh Mackie (California State University) for comments on bryozoans, Drs Olivier De Clerck and Heroen Verbruggen (Gent University, Belgium) for advice on some macroalgae, and Dr Gustaaf Hallegraeff (University of Tasmania) for comments on toxic dinoflagellates.

\section{REFERENCES}

Adachi, M., Kanno, T., Matsubara, T., Nishijima, T., Itakura, S. and Yamaguchi, M. (1999). Promotion of cyst formation in the toxic dinoflagellate Alexandrium (Dinophyceae) by natural bacterial assemblages from Hiroshima Bay, Japan. Marine Ecology Progress Series 191: 175-185.

Ahyong, S.T. (2005). Range extension of two invasive crab species in eastern Australia: Carcinus maenas (Linnaeus) and Pyromaia tuberculata (Lockington). Marine Pollution Bulletin 50: 460-462.

Allen, F.E. (1953). Distribution of marine invertebrates by ships. Australian Journal of Marine and Freshwater Research 4: 307-316.

Allen, F.E. and Wood, E.J.F. (1950). Investigations on underwater fouling II. The biology of fouling in Australia: Results of a year's research. Australian Journal of Marine and Freshwater Research 1: 92-105.

Alonso de Pina, G.M. (1997). Records of intertidal amphipods from the southwest Atlantic, with the description of a new species of Elasmopus. Journal of Crustacean Biology 17: 745-757.

Anderson, D.M., Chisholm, S.W. and Watras, C.J. (1983). Importance of life cycle events in the population dynamics of Gonyaulax tamarensis. Marine Biology 76: 179-189.

Anderson, D.M., Kulis, D.M., Doucette, G.J., Gallagher, J.C. and Balech, E. (1994). Biogeography of toxic dinoflagellates in the genus Alexandrium from the northeastern United States and Canada. Marine Biology 120: 467-478.

Anonymous. (1985). Ballast water hides unwanted immigrants. Australian Fisheries 44: 38.

Aquenol (2001). Exotic Marine Pest Survey, Port of Launceston, Tasmania. Report prepared for Port of Launceston. $104 \mathrm{pp}$.

Bale, W.M. (1888). On some new and rare Hydroida in 
the Australian Museum collection. Proceedings of the Linnean Society of New South Wales 3: 745-799.

Banta, W.C. (1969). The recent introduction of Watersipora arcuata Banta (Bryozoa, Cheilostomata) as a fouling pest in southern California. Bulletin of the Southern Californian Academy of Science 68: 248251.

Barnard, J.L. (1970). Sublittoral Gammaridea (Amphipoda) of the Hawaiian Islands. Smithsonian Contributions to Zoology 34: 1-279.

Bishop, M.W.H. (1947). Establishment of an immigrant barnacle in British coastal waters. Nature 159: 501.

Bishop, M.W.H. (1951). Distribution of barnacles by ships. Nature 167: 531.

Bishop, M.W.H. and Crisp, D.J. (1957). The Australasian barnacle, Elminius modestus, in France. Nature 179: $482-483$.

Black, J.H. (1971). Benthic communities. Memoirs of the Museum of Victoria 32: 129-170.

Blake, J.A. and Kudenov, J.D. (1978). The Spionidae (Polychaete) from southeastern Australia and adjacent areas with a revision of the genera. Memoirs of the National Museum of Victoria 39: 171-280.

Blanchard, M. (1995). Origine et état de la population de Crepidula fornicata (Gastropoda Prosobranchia) sur le littoral française. Haliotis 24: 75-86.

Blanchard, M. (1997). Spread of the slipper limpet Crepidula fornicata (L. 1758) in Europe. Current state and consequences. Scientia Marina 61: 109-118.

Bock, P.E. (1982). Bryozoans (Phylum Bryozoa). In: Shepherd, S.A. and Thomas, I.M. (eds), Marine invertebrates of southern Australia. Part 1: 319-394. Government Printer South Australia, Adelaide.

Bodeker, P. (1985). Fishy story that could keep growing. Daily News (Western Australia). 30/4/85: 14.

Boero, F. and Bouillon, J. (1993). Zoogeography and life cycle patterns of Mediterranean hydromedusae (Cnidaria). Biological Journal of the Linnean Society 48: 239-266.

Bolch, C.J.S. and Reynolds, M.J. (2002). Species resolution and global distribution of microreticulate dinoflagellate cysts. Journal of Plankton Research 24: 565-578.

Bolch, C.J.S., Negri, A.P. and Hallegraeff, G.M. (1999). Gymnodinium microreticulatum sp. nov. (Dinophyceae): a naked microreticulate cystproducing dinoflagellate, distinct from Gymnodinium catenatum Graham and Gymnodinium nolleri Ellegaard et Moestrup. Phycologia 38: 301-313.

Brearley, A., Chalermwat, K. and Kakhai, N. (2003). Pholadidae and Teredinidae (Mollusca: Bivalvia) collected from mangrove habitats on the Burrup Peninsula, Western Australia. In: Wells, F.E., Walker, D.I., and Jones, D.S. (eds), Proceedings of the Eleventh International Marine Biological Workshop: The Marine Flora and Fauna of Dampier, Western Australia: 345-361. Western Australian Museum, Perth.

Brenchley, G. A. and Carlton, J. T. (1983). Competitive displacement of native mud snails by introduced periwinkles in the New England intertidal zone. Biological Bulletin 165: 543-558.
Briggs, E.A. (1914). Hydrozoa from one hundred fathoms, seven miles east of Cape Pillar, Tasmania. Records of the Australian Museum 10: 285-302.

Brinckman-Voss, A. (1996). Seasonality of hydroids (Hydrozoa, Cnidaria) from an intertidal pool and adjacent subtidal habitats at race Rocks, off Vancouver Island, Canada. Scientia Marina 60: 89-97.

Broch, H. (1916). Results of Dr E. Mjoberg's Swedish scientific expeditions to Australia 1910-1913. VIII Cirripedien. Kungliga Svenska vetenskapsakadamiens handlingar 52: 3-16.

Brock, B.J. (1985). South Australian fouling Bryozoa. In: Nielsen, C. and Larwood, G.P. (eds), Bryozoa: Ordovician to Recent. Papers presented at the International Conference on Bryozoa, Vienna, 1982: 45-49. Olsen and Olse, Fredensborg.

Bruce, N. (1986). Cirolanidae (Crustacea: Isopoda) of Australia. Records of the Australian Museum, Supplement 6: 1-239.

Calder, D.R. (1991). Shallow-water hydroids of Bermuda: the Thecatae, exclusive of Plumularioidea. Royal Ontario Museum, Life Sciences Contributions 154: 1140.

Campbell, D. (1994). Translocation of exotic marine organisms in ballast water - why worry? AQIS Ballast Water Symposium Proceedings, Canberra, 11-13 May, 1994, Australian Government Publishing Service, Canberra.

Campbell, M.L. (2003a). Introduced species port baseline survey. Geraldton, Western Australia. Final Survey Report. Corporate Process Management, Perth, Western Australia. 45 pp.

Campbell, M.L. (2003b). Introduced species port baseline survey. Esperance, Western Australia. Final Survey Report. Corporate Process Management, Perth, Western Australia. 55 pp.

Carey, J.M. and Watson, J.E. (1992). Benthos of the muddy bottom habitat of the Geelong Arm of Port Phillip Bay, Victoria, Australia. Victorian Naturalist 109: 196-202.

Carlton, J.T. (1985). Transoceanic and interoceanic dispersal of coastal marine organisms. The biology of ballast water. Oceanography and Marine Biology Annual Review 23: 13-374.

Chalmer, P.N., Hodgkin, E.P. and Kendrick, G.W. (1976). Benthic faunal changes in a seasonal estuary of southwestern Australia. Records of the Western Australian Museum 4: 383-410.

Chang, F.H. and McClean, M. (1997). Growth responses of Alexandrium minutum (Dinophyceae) as a function of three different nitrogen sources and irradiance. New Zealand Journal of Marine and Freshwater Research 31: 1-7.

Chapman, J. W. and Carlton, J. T. (1991). A test of criteria for introduced species: the global invasion by the isopod Synidotea laevidorsalis (Miers, 1881). Journal of Crustacean Biology 11: 386-400.

Chapman, J.W. and Carlton, J.T. (1994). Predicted discoveries of the introduced isopod Synidotea laevidorsalis (Miers, 1881). Journal of Crustacean Biology 14: 700-714.

Cheshire, A., Westphalen, G., Boxall, V., Marsh, R., Gilliland, J., Collings, G., Seddon, S. and Loo, M. 
(2002). Caulerpa taxifolia in West Lakes and the Port River: distribution and eradication options. South Australian Research and Development Institute, Aquatic Sciences and PIRSA Fisheries, Marine Habitat Program. Internal report. 43 pp.

Chubb, C.F., Hutchins, J.B., Lenanton, R.C.J. and Potter, I.C. (1979). An annotated checklist of the fishes of the Swan-Avon River System, Western Australia. Records of the Western Australian Museum 8: 1-55.

Clapin, G and Evans, D.R. (1995). The status of the introduced marine fanworm Sabella spallanzanii in Western Australia: A preliminary investigation. CSIRO Technical Report, No. 2. Division of Fisheries, CSIRO, Hobart. 34 pp.

Coghlan, B. and Gosling, E. (2007). Genetic structure of hybrid mussel populations in the west of Ireland: two hypotheses revisited. Marine Biology 150: 841-852.

Cohen, B.F., McArthur, M.A., and Parry, G.D. (2001). Exotic marine pests in the Port of Melbourne. Report No. 25, Marine and Freshwater Resources Institute, Queenscliff, Victoria. 68pp.

Coleman, N. (1986). A review of the introduction of the Pacific oyster (Crassostrea gigas) around the world and a discussion of the possible ecological consequences of introducing the species into Victoria, Australia. Marine Science Laboratories, Technical Report, No. 56. 39 pp.

Coleman, N. (1993). The macrobenthos of Corio Bay. SRS 91/010 EPA (Vic). 34 pp

Coleman, N. and Hickman, N. (1986). Pacific oyster found in Victoria. Australian Fisheries 45(6): 8, 10.

Coppejans, E., Leliaert, F. and Verbruggen, H. (2005). Green algae. Chlorophyceae. Guide to the seaweeds of KwaZulu Natal. Scripta Botanica Belgica 33: 39-93.

Costello, M.J. (1993). Biogeography of alien amphipods occurring in Ireland, and interactions with native species. Crustaceana 65: 287-299.

Cotton, B.C. South Australian Mollusca. Archaeogastropoda. W.A. Hawes, Government Printer, Adelaide.

Courtnay, W. R. (1990). Fish introductions and translocations, and their impacts in Australia. In: Pollard, D. A. (ed.), Introduced and translocated fishes and their ecological effects. Bureau of Rural Resources Proceedings No. 8: 171-179. Department of Primary Industries and Energy, Canberra.

CRIMP (1997a). Introduced Species Survey, Port of Bunbury, Western Australia. CSIRO Marine Research. $\mathrm{vi}+52 \mathrm{pp}$.

CRIMP (1997b). Introduced Species Survey, Port of Albany, Western Australia. CSIRO Marine Research. $\mathrm{vi}+41 \mathrm{pp}$.

CRIMP (1999). Introduced Species Survey, Port Hedland, Western Australia. CSIRO Marine Research. vi + 46 pp.

CRIMP (2000). Introduced Species Survey Final Report, Fremantle, Western Australia. CSIRO Marine Research. vi +61 pp.

Crisp, D. J. (1958). The spread of Elminius modestus Darwin in northwest Europe. Journal of the Marine Biological Association of the U.K. 37: 483-520.
Currie, D.R., McArthur, M.A. and Cohen, B.F. (1998). Exotic marine pests in the Port of Geelong, Victoria. Report No. 8, Marine and Freshwater Resources Institute, Queenscliff, Victoria. $65 \mathrm{pp}$.

Currie, D.R., McArthur, M.A. and Cohen, B.F. (2000). Reproduction and distribution of the invasive European fanworm Sabella spallanzanii in Port Phillip Bay, Victoria, Australia. Marine Biology 136: 645-656.

Department of Agriculture, Fisheries and Forestry. 2006 Màrine Pest Monitoring Manual. Version 1. Department of Agriculture Fisheries and Forestry, Canberra. 126 pp.

DALSE (2004). Pilbara Iron Ore and Infrastructure Project. Marine Environmental Impacts and their Management. Prepared for Fortescue Metals Group by DAL Science and Engineering Pty Ltd, July 2004. Report No. 389/1. v +52 pp.

Dartnall, A. J. (1969). New Zealand sea stars in Tasmania. The Papers and Proceedings of the Royal Society of Tasmania 103: 53-55.

Darwin, C. (1854). A monograph on the subclass Cirripedia, with figures of all the species. The Balanidae, the Verrucidae etc. Ray Society, London. $684 \mathrm{pp}, 30$ pls.

Day, J.H. (1975). On a collection of Polychaeta from intertidal and shallow reefs near Perth, Western Australia. Records of the Western Australian Museum 3: 167-208.

Dinamani, P. (1971). Occurrence of the Japanese Oyster Crassostrea gigas (Thunberg), in Northland, New Zealand. New Zealand Journal of Marine and Freshwater Research 5: 352-357.

Dorsey, J.H. (1982). Intertidal community offshore from the Werribee Sewage Treatment Farm: an opportunistic infaunal assemblage. Australian Journal of Marine and Freshwater Research 33: 45-54.

Dyrynda, P.E.J., Fairall, A., Occhipinti Ambrogi, A., d'Hondt, J.-L. (2001). The distribution, origins and taxonomy of Tricellaria inopinata $\mathrm{d}$ 'Hondt and Occhipinti Ambrogi, 1995, an invasive bryozoan new to the Atlantic. Journal of Natural History 34: 1993 2006.

Ewers, W.H. 1967. The distribution of Velacumantus australis (Gastropoda: Potamididae). Australian Journal of Zoology 15: 581-591.

Fearn-Wannan, H.J. (1968). Littoral Amphipoda of Victoria. Part II. Proceedings of the Royal Society of Victoria 81: 127-136.

Fisheries Western Australia. (2000). Introduced Marine Aquatic Invaders. Fisheries Western Australia, Perth. $27 \mathrm{pp}$.

Foster, B.A. (1978). The marine fauna of New Zealand: Barnacles (Cirripedia, Thoracica). Memoirs of the New Zealand Oceanographic Institute 69: 1-160.

Fraser, C.M. (1948). Hydroids of the Allan Hancock Pacific expeditions since March, 1938. Allan Hancock Pacific Expeditions 4: 179-335.

Friese, U.E. (1973). Another Japanese goby in Australian waters; what next? Koolewong 2: 5-6.

Fulton, S.W. and Grant, F.E. (1900). Note on the occurrence of the European crab, Carcinus maenas, 
Leach, in Port Phillip. The Victorian Naturalist 17: 147-148.

Fulton, S.W. and Grant, F.E. (1901). Some little known Victorian decapod Crustacea with description of a new species. Proceedings of the Royal Society of Victoria 14: 55-64.

Furlani, D.M. (1996). A guide to the introduced marine species in Australian waters. Centre for Research on Introduced Marine Pests, Commonwealth Scientific and Industrial Research Organisation, Division of Fisheries, Hobart, Tasmania, Division of Fisheries Technical Report No. 5: unpaginated.

Geiger, D.L. (2000). Distribution and biogeography of the Recent Haliotidae (Gastropoda, Vetigastropoda) world-wide. Bolettino Malacologico 35: 57-120.

Geiger, D.L. and Poppe, G.T. (2000). The Family Haliotidae. In: Poppe, G.T. and Groh, K. (eds), A Conchological Iconography. ConchBooks, HackenHeim, Germany. 135 pp.

Geller, J.B., Carlton, J.T. and Powers, D.A. (1993). Interspecific and interpopulation variation in mitochondrial ribosomal DNA sequences of Mytilus spp (Bivalvia: Mollusca). Molecular Marine Biology and Biotechnology 21: 44-50.

George, D. and George, J. (1979). Marine Life. Rigby, Adelaide, South Australia. 288 pp.

Giacobbe, M.G., Oliva, F.D. and Maimone, G. (1996). Environmental factors and seasonal occurrence of the dinoflagellate Alexandrium minutum, a PSP potential producer, in a Mediterranean lagoon. Estuarine, Coastal and Shelf Science 42: 539-549.

Gofas, S. and Zenetos, A. (2003). Exotic molluscs in the Mediterranean basin: Current status and perspectives. Oceanography and Marine Biology: an Annual Review 41: 237-277.

Gomon, M.F., Glover, J.C.M. and Kuiter, R.H. (eds) (1994). The fishes of Australia's south coast. State Print, Adelaide. 992 pp.

Gordon, D.P. (1984). The marine fauna of New Zealand: Bryozoa: Gymnolaemata from the Kermadec Ridge. New Zealand Oceanographic Institute Memoirs 91: 1-198.

Gordon, D.P. (1986). The marine fauna of New Zealand: Bryozoa: Gymnolaemata (Ctenostomata and Cheilstomata Anasca) from the Western South Island and continental shelf and slope. New Zealand Oceanographic Institute Memoirs 95: 1-121.

Gordon, D.P. (1989). The marine fauna of New Zealand: Bryozoa: Gymnolaemata (Cheilostomida Ascophorina) from the Western South Island Continental Shelf and Slope. New Zealand Oceanographic Institute Memoirs 97: 1-158.

Gordon, D.P. and Mawatari, S.F. (1992). Atlas of marinefouling Bryozoa of New Zealand ports and harbours. New Zealand Oceanographic Institute Memoirs 107: $1-52$.

Gosliner, T. M. (1982). A new record of the nudibranch Polycera hedgpethi Marcus from the Indian Ocean of South Africa. Journal of Molluscan Studies 48: 30-35.

Grave, B.H. (1928). Natural history of shipworm, Teredo navalis, at Woods Hole. Massachusetts Biological Bulletin (Woods Hole) 55: 260-282.
Gravier, N. (1970), Étude des hydraires epiphytes des phanérogames marines de la region de Tulear (sudouest de Madagascar). Recueil des Travaux de la Station Marine d'Endoume, suppl. 10: 111-161.

Gravier-Bonnet, N. and Bourmaud, C.A-F. (2006). Hydroids (Cnidaria, Hydrozoa) of Coral Reefs: Preliminary results on community structure, species distribution and reproductive biology in Juan de Nova Island (southwest Indian Ocean). Western Indian Ocean Journal of Marine Science 5: 123-132.

Grosholz, E.D. and Ruiz, G.M. (1995). The spread and potential impact of the recently introduced European green crab, Carcinus maenas, in central California. Marine Biology 122: 239-247.

Guiry, M.D. and Guiry, G.M. (2007). AlgaeBase version 4.2. World-wide electronic publication, National University of Ireland, Galway. http:// www.algaebase.org; searched on 10 May 2007.

Hallegraeff, G.M. and Bolch, C.J. (1991). Transport of toxic dinoflagellate cysts via ships' ballast water. Marine Pollution Bulletin 22: 27-30.

Hallegraeff, G.M. and Bolch, C.J. (1992). Transport of diatom and dinoflagellate resting spores in ships' ballast water: implications for plankton biogeography and aquaculture. Journal of Plankton Research 14: 1067-1084.

Hallegraeff, G.M. and Hosja, W. (1993). Bunbury Port Survey for dinoflagellate cysts: Aquaculture site evaluation and potential ballast water risks. Report to the South West Development Authority. Unpaginated.

Hallegraeff, G. M., Steffensen, D. A. and Wetherbee, R. (1988): Three estuarine Australian dinoflagellates that can produce paralytic toxic shellfish toxins. Journal of Plankton Research 10: 533-41.

Hallegraeff, G.M., Valentine, J.P., Marshall, J-A. and Bolch, C.J. (1997). Temperature tolerances of toxic dinoflagellate cysts: application to the treatment of ships' ballast water. Aquatic Ecology 31: 47-52.

Harrison, K. and Holdich, D.M. (1982a). Revision of the genera Dynamenella, Ischyromene, Dynamenopsis and Cymodocella (Crustacea: Isopoda), including a new genus and five new species of eubranchiate sphaeromatids from Queensland waters. Journal of Crustacean Biology 2: 84-119.

Harrison, K. and Holdich, D.M. (1982b). New eubranchiate sphaeromatid isopods from Queensland waters. Memoirs of the Queensland Museum 20: 421446.

Hartmann-Schröder, G. and Hartmann, G. (1981). Zur Kenntnis des Eulitorals der australischen Küsten unter besonderer Berücksichtigung der Polychaeten und Ostracoden (Teil 6 and Teil 7). HartmannSchröder, G. Teil 6. Die Polychaeten der tropischsubtropischen Westküste Australiens (zwischen Exmouth im Norden und Cervantes im Süden). Mitteilungen aus dem Hamburgischen Zoologischen Museum und Institut 78: 19-96.

Hartmann-Schröder, G. and Hartmann, G. (1982). Zur Kenntnis des Eulitorals der australischen Küsten unter besonderer Berücksichtigung der Polychaeten und Ostracoden. Hartmann-Schröder, G. Teil 8. Die Polychaeten der tropisch-antiborealen Westküste 
Australiens (zwischen Exmouth im Norden und Cervantes im Süden). Mitteilungen aus dem Hamburgischen Zoologischen Museum und Institut 79: 51-118.

Hartmann-Schröder, G. and Hartmann, G. (1989). Zur Kenntnis des Eulitorals der australischen Küsten unter besonderer Berücksichtigung der Polychaeten und Ostracoden. Hartmann-Schröder, G. Teil 14. Die poylchaeten der antiborealen und subtropischtropischen Küste Südost-Australiens zwischen Lakes Entrance (Victoria) im Süden und Maclean (New South Wales) im Norden. Mitteilungen aus dem Hamburgischen Zoologischen Museum und Institut 86: 11-63.

Hartmeyer, R. and Michaelsen, W. (1928). Ascidiae Diktyobranchia und Ptychobranchiae. In: Hartmeyer, R. and Michaelsen, W. (eds), Die Fauna SüdwestAustraliens 5: 251-460. Gustav Fischer, Jena.

Harvey, H. and Beard, I. (1985). Bilgewater Bream Breaks Quarantine. Modern Fishing, June: 28.

Hass, C.G. and Knott, B. (1998). Sphaeromatid isopods from the Swan River, Western Australia: diversity, distribution and geographic sources. Crustaceana 71: $36-46$.

Hass, C. G. (2007). Isopoda. In: Fromont, J. (ed.), Strategic Research Fund for the Marine Environment Collaborative Research Project: Biodiversity of Marine Fauna on the Central West Coast. SRFME Final Milestone Report - December 2006: pp 26-27.

Hass, C.G. and Jones, D.S. (1999). Marine introductions to Western Australia, with a focus on crustaceans: 3744. In: Kesby, J. A., Stanley, J. M., McLean, R. F. and Olive, L. J. (eds), Geodiversity: Readings in Australian geography at the close of the $20^{\text {th }}$ century. Special publication Series No. 6, Canberra, ACT, School of Geography and Oceanography, University College, Australian Defence Force Academy. 630 pp.

Haswell, W.A. (1885). On a destructive parasite of the rock oyster. (Polydora ciliata and $P$. polybranchia n.sp.). Proceedings of the Linnean Society of New South Wales 10: 273-275.

Hayward, P.J. and Ryland, J.S (1979). British ascophoran bryozoans: Keys and notes for the identification of the species. Academic Press, London. 312 pp.

Herdman, W.A. (1899). Descriptive catalogue of the Tunicata in the Australian Museum. Australian Museum, Sydney, Catalogue 17: 1-139.

Hewitt, C.L. and Campbell, M.L. (2001). The Australian distribution of the introduced sphaeromatid isopod, Paracerceis sculpta. Crustaceana 74: 925-936.

Hewitt, C.L. (2003). The diversity of likely impacts of introduced marine species in Australian waters. Records of the South Australian Museum Monograph Series 7: 3-10.

Hewitt C.L., Campbell, M.L., Thresher, R.E., Martin, R.B., Boyd, S., Cohen, B.F., Currie, D.R., Gomon, M.F., Keough, M.J., Lewis, J.A., Lockett, M.M., Mays, N., McArthur, M.A., O'Hara, T.D., Poore, G.C.B., Ross, D.J., Storey, M.J., Watson, J.E. and Wilson, R.S. (2004). Introduced and cryptogenic species in Port Phillip Bay, Victoria, Australia. Marine Biology 144: 183-202.

Hiscock, K., Hiscock, S. and Baker, J.M. (1978). The occurrence of the barnacle Elminius modestus in Shetland. Journal of the Marine Biological Association of the United Kingdom 58: 627-629.

Hodgson, M. (1950). A revision of the Tasmanian Hydroida. Papers and Proceedings of the Royal Society of Tasmania for the Year 1949: 1-65.

Hoese, D.F. (1973). The introduction of the gobiid fishes Acanthogobius flavimanus and Tridentiger trigonocephalus into Australia. Koolewong 2: 3-5.

Holdich, D.M. and Harrison, K. (1983). Sphaeromatid isopods (Crustacea) from brackish waters in Queensland. Zoologica Scripta 12: 127-140.

Hove, H. A. ten and Weerdenburg, J.C.A. (1978). A generic revision of the brackish-water serpulid Ficopomatus Southern, 1921 (Polychaeta: Serpulinae), including Mercierella Fauvel, 1923, Sphaeropomatus Treadwell, 1934, Mercierellopsis Rioja, 1945 and Neopomatus Pillau, 1960. Biological Bulletin 154: 96120.

Huisman, J.M. (1997). Marine benthic algae of the Houtman Abrolhos Islands, Western Australia. In: Wells, F.E. (ed.), The Marine Flora and Fauna of the Houtman Abrolhos Islands, Western Australia: 177237. Western Australian Museum, Perth

Huisman, J.M. (2000). Marine Plants of Australia. University of Western Australia Press, Nedlands. ix + $300 \mathrm{pp}$.

Huisman, J.M. and Borowitzka, M.A. (2003). Marine benthic flora of the Dampier Archipelago, Western Australia. In: Wells, F.E., Walker, D.I. and Jones, D.S. (eds), The Marine Flora and Fauna of Dampier, Western Australia: 291-344. Western Australian Museum, Perth.

Huisman, J.M., Phillips, J. and Parker, C. (2006). Marine Plants of the Perth Region. Department of Environment and Conservation, Perth. 72 pp.

Hurlbut, C.J. (1991). Community recruitment: settlement and juvenile survival of seven co-occurring species of sessile marine invertebrates. Marine Biology 109: 507515.

Hurley, D.E. (1954). Studies on the New Zealand amphipodan fauna. No. 7. The Family Corophiidae, including a new species of Paracorophium. Transactions of the Royal Society of New Zealand 82: $431-460$.

Hutchings, P.A, Hilliard, R.W.L. and Coles, S. 2002. Species introductions and potential for marine pest invasions into tropical marine communities, with special reference to the Indo-Pacific. Pacific Science 56: 223-233.

Hutchings, P. and Murray, A. (1984). Taxonomy of polychaetes from the Hawkesbury River and the southern estuaries of New South Wales, Australia. Records of the Australian Museum, 36, Supplement 3: 1-118.

Hutchings, P.A. and Turvey, S.P. (1984). The Spionidae of South Australia (Annelida Polychaeta). Transactions of the Royal Society of South Australia 108: $1-120$.

Hutchings, P.A., van der Velde, J.T. and Keable, S.J. (1986). Colonisation of New South Wales by nonindigenous marine species. Baseline studies at 
Twofold Bay, New South Wales. Unpublished final report to the Fisheries Industry Research Committee. FIRTA 84-49. 71 pp.

Hutchings, P.A., van der Velde, J.T. and Keable, S. J. (1987). Guidelines for the conduct of surveys for detecting introductions of non-indigeneous marine species by ballast water - and a review of marine introductions to Australia. Final Report to FIRC, FIRTA 86/110. Occasional Reports of the Australian Museum 3: 1-147.

Hutchings, P., van der Velde, J., Keable, S. (1989). Baseline survey of the benthic macrofauna of Twofold Bay, N.S.W, with a discussion of the marine species introduced into the bay. Proceedings of the Linnean Society of New South Wales 110: 339-367.

Johnson, W.S. (1976). Biology and population dynamics of the isopod Cirolana harfordi. Marine Biology 36: 343-350.

Jones, D.S. (1987a). A key to the common sessile barnacle species in the Swan-Canning river estuary, Western Australia. In: John, J. (ed.), Swan River estuary, Ecology and Management. Curtin University Environmental Studies Group, Report Number 1: 153-162.

Jones, D.S. (1987b). Preliminary investigations on the barnacles of the Swan-Canning river estuary. In: J. John (ed.), Swan River estuary, Ecology and Management. Curtin University Environmental Studies Group, Report Number 1: 141-152.

Jones, D.S. (1990a). The shallow-water barnacles (Cirripedia: Lepadomorpha, Balanomorpha) of southern Western Australia. In: Wells, F.E., Walker, D.I., Kirkman, H. and Lethbridge, R. (eds), Proceedings of the Third International Marine Biological Workshop: The Marine Flora and Fauna of Albany, Western Australia, 1988: 333 - 437. Western Australian Museum, Perth.

Jones, D.S. (1990b). A guide to the shallow-water barnacles (Cirripedia: Lepadomorpha, Balanomorpha) of the Shark Bay area, Western Australia. In: Berry, P.F., Bradshaw, S.D. and Wilson, B.R. (eds), Research in Shark Bay - Report of the France-Australe Bicentenary Expedition Committee: 209-229. Western Australian Museum, Perth.

Jones, D.S. (1990c). Occurrence of the barnacle Tesseropora rosea (Krauss) (Thoracica, Balanomorpha, Tetraclitidae) in western Australian waters. Records of the Western Australian Museum 14: 665-668.

Jones, D.S. (1991). A history of the discovery and description of Australian barnacles (Cirripedia, Thoracica), including a bibliography of reference works. Archives of Natural History 18: 149-178.

Jones, D.S. (1992a). A review of Australian fouling barnacles. Asian Marine Biology 9: 89-100.

Jones, D.S. (1992b). Barnacles. In: G. J. Morgan (ed.), Aquatic fauna of the Kimberley islands and reefs, Western Australia, pp 49-55. Western Australian. Museum, Perth.

Jones, D.S. (1999a). Cirripedia of the Port of Fremantle Introduced Marine Pests Survey. Report prepared for Murdoch University, Perth: 4 pp. Western Australian Museum, Perth. Unpublished report.
Jones, D.S. (1999b). Cirripedia of the Port of Darwin Introduced Marine Pests Survey. Report prepared for the Northern Territory Museum and Art Gallery: 20 pp. Western Australian Museum, Perth. Unpublished report.

Jones, D. S. (2000a). Preliminary identification of Crustaceans from the Vessel 'Leonardo da Vinci' in Geraldton Harbour. Report to URS Australia Pty Ltd.: 6 pp. Western Australian Museum, Perth. Unpublished report.

Jones, D.S. (2000b). Cirripedia of the Port Botany Introduced Marine Pests Survey. Report prepared for the New South Wales Fisheries Research Institute: 11 pp. Western Australian Museum, Perth. Unpublished report.

Jones, D.S. (2001a). Cirripedia of the Port Kembla Introduced Marine Pests Survey. Report prepared for the New South Wales Fisheries Research Institute: 11 pp. Western Australian Museum, Perth. Unpublished report.

Jones, D.S. (2001b). Cirripedia from the Australian Museum Sydney Ports Introduced Marine Pests Survey. Report prepared for the Australian Museum Sydney: 3 pp. Western Australian Museum, Perth. Unpublished report.

Jones, D.S. (2002). Cirripedia of the Port of Esperance Introduced Marine Pests Survey. Report to Esperance Port Authority: 5 pp. Western Australian Museum, Perth. Unpublished report.

Jones, D.S. (ed.). (2004a). Report on the results of the Western Australia Museum/Woodside Energy Ltd. Partnership to explore the Marine Biodiversity of the Dampier Archipelago, Western Australia 1998-2002. Records of the Western Australian Museum, Supplement 66: 1-401.

Jones, D.S. (2004b). Barnacles (Cirripedia: Thoracica) of the Dampier Archipelago, Western Australia. In: Jones, D. S. (ed.), Report on the results of the Western Australia Museum/Woodside Energy Ltd. Partnership to explore the Marine Biodiversity of the Dampier Archipelago, Western Australia 1998-2002. Records of the Western Australian Museum, Supplement 66: 121-157.

Jones, D.S. (2005). Introduced marine species in the waters of Barrow Island, with emphasis on barnacle species. Report to ChevronTexaco Australia Pty Ltd. 14 pp. Western Australian Museum, Perth. Unpublished report.

Jones, D.S. and Berry, P F. (2000). Crustacea of the Montebello Islands. In: Berry, P.F. and Wells, F.E. (eds), Survey of the Marine Fauna and Habitats of the Montebello Islands, Western Australia. Records of the Western Australian Museum, Supplement 59: 59-63.

Jones, D.S. and Hewitt, M.A. (1996). Barnacles (Cirripedia). In: Hutchins, J.B., Slack-Smith, S.M., Bryce, C.W., Morrison, S.M. and Hewitt, M.A. (eds), Marine Biological Survey of the Muiron Islands and the eastern shore of Exmouth Gulf. Report to the Ocean Rescue 2000 Program (Project number G0012/ 94), February, 1996: 43-53. Western Australian Museum, Perth.

Jones, D.S. and Hewitt, M.A. (1997). Barnacles (Cirripedia). In: Walker, D.I. (ed.), Marine Biological 
Survey of the Central Kimberley Coast, Western Australia (National Estates Grant Program Project), December, 1996: 91-95. University of Western Australia, Perth.

Jones, D.S. and Hewitt, M. (2001). Crustaceans, pp 15-19. In: Geraldton Port Survey Identification of Specimens. Report prepared by Department of Aquatic Zoology, WA Museum, August 2001, for the Geraldton Port Authority: 29 pp. Western Australian Museum, Perth. Unpublished report.

Jones, D.S., Anderson, J.T. and Anderson, D.T. (1990). Checklist of the Australian Cirripedia. Technical Reports of the Australian Museum, Number 3: 1-28.

Jousson, O., Pawlowski, J., Zaninetti, L., Zechman, F.W., Dini F., Di Guiseppe G., Woodfield R. and Millar, A. (2000). Invasive alga reaches California. Nature (London) 408: 157-58.

Kendrick, G., Harvey, E., McDonald, J., Wells, F.E. and Walker, D.I. (2005). Introduction to the marine biology of the Recherche Archipelago, Western Australia. Pp. 1-10. In: Wells, F.E., Walker, D.I., and Kendrick, G. (eds), The Marine Flora and Fauna of Esperance, Western Australia. Western Australian Museum, Perth.

Keough, M.J. (1989). Dispersal of the bryozoa Bugula neritina and effects of adults on newly metamorphosed juveniles. Marine Ecology Progress Series 57: 163-171.

Keough, M.J. and Ross, J. (1999). Introduced fouling species in Port Phillip Bay. In: Hewitt, C.L., Campbell, M.L., Thresher, R.E. and Martin, R.B. (eds), Marine biological invasions of Port Phillip Bay, Victoria. Centre for Research on Introduced Marine Pests Technical Report No. 20: 193-226. CSIRO Marine Research, Hobart, Tasmania, Australia.

Kilburn, R.N. and Rippey, E. (1982). Sea Shells of Southern Africa. Capetown, Macmillan, South Africa. 249 pp.

Knox, G.A. and Cameron, D.B. (1971). Port Phillip Bay Survey Part 2. Chapter 4. Polychaeta. Memoirs of the National Museum of Victoria 32: 21-41.

Kott, P. (1952). Ascidians of Australia. 1. Stolidobranchiata and Phlebobranchiata. Australian Journal of Marine and Freshwater Research 3: 206333.

Kott, P. (1985). The Australian Ascidiacea. Part 1: Phlebobranchia and Stolidobranchia. Memoirs of the Queensland Museum 23: 1-438.

Kott, P. (1990). The Australian Ascidiacea. Part 2: Aplousobranchia. Memoirs of the Queensland Museum 29: 1-266.

Kott, P. (1997). Tunicates (sub-phylum Tunicata). In: Shepherd, S.A. and Davies, M. (eds), Marine Invertebrates of Southern Australia Part III: 1092 1255. South Australian Research and Development Institute (Aquatic Sciences) and the Flora and Fauna of South Australia Handbooks Committee.

Kowarsky, J. (1969). A preliminary study of Parcnassa burchardi (Philippi) (Mollusca, Gastropoda, Nassariidae) in the Swan River estuary. BSc(Hons) thesis, University of Western Australia.

Krauss, F. (1848). Die sudafrikanischen Mollusken. Ein Beitrag zur Kenntniss der Mollusken des Kap-und
Natal-landes und zur geographischen Verbreitung derselben, mit Beschreibung und Abbildung der neuen Arten. Stuttgart.

Lamarck, J.-B. (1819). Histoire naturelle des animaux sans vertebras. Tome 6 . Paris.

Lambert, C.C. and Lambert, G. (1998). Non-indigenous ascidians in southern California harbors and marinas. Marine Biology 130: 675-688.

Lewis, J.A. (1979). Marine biofouling at the North Barnard Islands, Queensland. Department of Defence: Defence Science and Technology Organisation, Materials Research Laboratories, Melbourne. Report MRL-R-740: 21 pp.

Lewis, J.A. (1981a). Records of Australian fouling organisms: Sessile barnacles (Crustacea: Cirripedia). Australian Department of Defence, Defence Science and Technology Organisation, Materials Research Laboratories. Report MRL-R- 809: 13 pp.

Lewis, J.A. (1981b). Settlement of fouling organisms at the JTTRE North Barnard Island Raft Site. Department of Defence: Defence Science and Technology Organisation, Materials Research Laboratories, Melbourne. Report MRL-TN-450: 3 pp.

Lewis, J.A. (1982). A guide to the principal marine fouling organisms, with particular reference to Cockburn Sound, Western Australia. Australian Department of Defence, Defence Science and Technology Organisation, Material Research Laboratory. Report MRL-R-858: 19 pp.

Lewis, J.A., Watson, C. and ten Hove, H.A. (2006). Establishment of the Caribbean serpulid tubeworm, Hydroides sanctaecrucis Krøyer [in] Mörch, 1863, in northern Australia. Biological Invasions 8: 665-671.

Lockett, M.M. and Gomon, M.F. (1999). Occurrence and distribution of exotic fishes in Port Phillip Bay. In: Hewitt, C.L., Campbell, M.L., Thresher, R.E. and Martin, R.B. (eds), Marine Biological Invasions of Port Phillip Bay, Victoria. Centre for Research on Introduced Marine Pests Technical Report No. 5: 178192. CSIRO Marine Research, Hobart, Tasmania, Australia.

Lockett, M.M. and Gomon, M.F. (2001). Ship mediated fish invasions in Australia: Two new introductions and a consideration of two previous invasions. Biological Invasions 3: 187-192.

Lovejoy, C., Bowman, J.P. and Hallegraeff, G.M. (1998). Algicidal effects of a novel marine Pseudoalteromonas isolate (Class Proteobacteria, Gamma Subdivision) on harmful algal bloom species of the genera Chattonella, Gymnodinium and Heterosigma. Applied and Environmental Microbiology 64: 2806-2813.

Ludbrook, N.H. (1984). Quaternary Molluscs of South Australia. Department of Mines and Energy, South Australia Handbook 9: 1-327.

Mackie, J.A., Keough, M.J., Christidis, L. (2006). Invasion patterns inferred from cytochrome oxidase I sequences in three bryozoans, Bugula neritina, Watersipora subtorquata, and Watersipora arcuata. Marine Biology 149: 285-295.

Macnae, W. (1954). On some eolidacean nudibranchiate molluscs from South Africa. Annals of the South African Museum 13: 1-50. 
Macpherson, J.H. (1953). Record of a South African mollusc from Australia (Haliotis sanguinea Hanley). Memoirs of the National Museum of Victoria 18: 169.

Marshall, J.V. and Turner, R.D. (1974). Survey of Marine Borers 1970-1972. The Family Teredinidae in Australian Waters. CSIRO Project P5-11. The University of New South Wales Project 12-045-15. $158 \mathrm{pp}$.

Matsuyama, Y., Miyamoto, M. and Kotani, Y. (1999). Grazing impacts of the heterotrophic dinoflagellate Polykrikos kofoidii on a bloom of Gymnodinium catenatum. Aquatic Microbial Ecology 17: 91-98.

McDonald, J. (2004): The invasive pest species Ciona intestinalis (Linnaeus, 1767) reported in a harbour in southern Western Australia. Baseline I. Marine Pollution Bulletin 49: 868-870.

McMinn, A., Hallegraeff, G.M., Thomson, P., Jenkinson, A.V. and Heijnis, $H$. (1997). Cyst and radionucleotide evidence for the recent introduction of the toxic dinoflagellate Gymnodinium catenatum into Tasmanian waters. Marine Ecology Progress Series 161: 165-172.

Medcof, J.C. and Wolf, P.H. (1975). Spread of Pacific oyster worries NSW culturists. Australian Fisheries 34: 32-38.

Millar, A.J.K. (2002) The introduction of Caulerpa taxifolia in New South Wales, Australia. In Williams, E. and Grosholz, E. (eds), International Caulerpa taxifolia conference proceedings: 79-87. California Sea Grant College, University of California - San Diego, La Jolla, CA.

Millar, A.J.K. and Kraft, G.T. (1984). The red algal genus Acrosymphyton (Dumontiaceae, Cryptonemiales) in Australia. Phycologia 23: 135-145.

Miller, M.C. (2001). Descriptions of the dorid nudibranchs Polycera hedgpethi Marcus, 1964 and $P$. fujitai Baba, 1837 in New Zealand. Journal of Molluscan Studies 67: 491-499.

Monroe, C.C.A. (1938). On a small collection of Polychaeta from the Swan River, Western Australia. Annals and Magazine of Natural History 11: 614-24.

Moran, P.J. and Grant, T.R. (1993). Larval settlement of marine fouling organisms in polluted water from Port Kembla Harbour, Australia. Marine Pollution Bulletin 26: 512-514.

Morgan, G. J. (1990). An introduced Pacific majid crab from Cockburn Sound, southwest Australia. Crustaceana 58: 316-317.

Morrison, H. and Wells. F.E. (2008). Colonisation of Fremantle Harbour and Cockburn Sound, Western Australia by the eastern Australian scallop Scaeochlamys livida (Lamarck, 1819). Molluscan Research 28.

Morton, B., Lam, K. and Slack-Smith, S. (2003). First report of the European flat oyster Ostrea edulis, identified genetically, from Oyster Harbour, Albany, south-western Western Australia. Molluscan Research 23: 199-208.

NIMPIS (2002). National Introduced Marine Pest Information System. Hewitt C.L., Martin R.B., Sliwa C., McEnnulty, F.R., Murphy, N.E., Jones T. and Cooper, S. (eds). Web publication <http:// crimp.marine.csiro.au/nimpis>. Date of access: various in 2007.

Ogata, T., Ishimaru, T. and Kodama, M. (1987). Effect of water temperature and light intensity on growth rate and toxicity change in Protogonyaulax tamarensis. Marine Biology 95: 217-220.

O'Riordan, R.M. and Ramsay, N.F. (1999). The current distribution and abundance of the Australasian barnacle Elminius modestus in Portugal. Journal of the Marine Biological Association of the United Kind tom 79: 937-939.

Osburn, R.C. (1950). Bryozoa of the Pacific coast of America, Part 1, Cheilostomata-Anasca. Allan Hancock Pacific Expeditions 14: 1-269.

Osburn, R.C. (1952). Bryozoa of the Pacific coast of America Part 2, Cheilostomata - Ascophora. Allan Hancock Pacific Expeditions 14: 271-611.

Osburn, R.C. (1953). Bryozoa of the Pacific coast of America, Part 3, Cyclostomata, Ctenostomata, Entoprocta, and addenda. Allan Hancock Pacific Expeditions 14: 613-841.

Padilla, D.K., Chotokowski, M.A. and Buchan, L.A.J. (1996). Predicting the spread of Zebra mussels (Dreissena polymorpha) to inland waters using boater movement patterns. Global Ecological and Biogeographical Letters 5: 353-359.

Paesanti, F., Carrieri, A. and Rossi, R. (1991). Risultati dell' introduzione di vongola filippina, Tapes philippinarum (Adams and Reeve, 1850), nella Sacca di Goro (Delta del Po). II Pesce 2: 51-57.

Parry, G.D., Currie, D.R. and Crookes, D.P. (1997). Exotic marine pests in Portland harbour and environs. Marine and Freshwater Resources Institute Report No. 1, Marine and Freshwater Resources Institute, Queenscliff, Victoria. 40pp.

Paxton, H. and Chou, L.M. (2000). Polychaetous annelids from the South China Sea. The Raffles Bulletin of Zoology Supplement 8: 209-232.

Paxton, J.R. and Hoese, D.F. (1985). The Japanese sea bass, Lateolabrax japonicus (Pisces, Percichtyidae), an apparent marine introduction into eastern Australia. Japanese Journal of Ichthyology 31: 369-372.

Pennycuik, P.R. (1959). Faunistic records from Queensland. Part V. - Marine and brackish water hydroids. University of Queensland Papers: Department of Zoology 1: 141-210.

Phillips, J.A. (1988). Field, anatomical and developmental studies on southern Australian species of Ulva (Ulvaceae, Chlorophyta). Australian Systematic Botany 1: 411-456.

Pollard, D.A. and Hutchings, P.A. (1990a). A review of exotic marine organisms introduced to the Australasian region, I. Fishes. Asian Fisheries Science 3: 205-221.

Pollard, D.A. and Hutchings, P.A. (1990b). A review of exotic marine organisms introduced to the Australasian region, II. Invertebrates and algae. Asian Fisheries Science 3: 223-250.

Pollard, D.A. and Rankin, B.K. (2003). Port of Eden Introduced Marine Pest Species Survey. Final Report to Coasts and Clean Seas Program. NSW Fisheries Final Report Series No. 46. 67pp. 
Poore, G. C. B. (1996). Species differentiation in Synidotea (Isopoda: Idoteidae) and recognition of introduced marine species: a reply to Chapman and Carlton. Journal of Crustacean Biology 16: 384-394.

Poore, G.C.B. and Rainer, S. (1974). Distribution and abundance of soft bottom molluscs in Port Phillip Bay, Victoria. Australian Journal of Marine and Freshwater Research 29: 371-411.

Poore, G.C.B. and Storey, M. (1999). Soft sediment Crustacea of Port Phillip Bay. In: Hewitt, C.L., Campbell, M.L., Thresher, R.E. and Martin, R.B. (eds), Marine biological invasions of Port Phillip Bay, Victoria. Centre for Research on Introduced Marine Pests Technical Report No. 20: 150-170. CSIRO Marine Research, Hobart, Tasmania, Australia.

Ralph, P.M. (1957). New Zealand thecate hydroids. Part I. Campanulariidae and Campanulinidae. Transactions of the Royal Society of New Zealand 84: 811-854.

Ralph, P.M. (1958). New Zealand thecate hydroids. Part II. Families Lafoeidae, Lineolariidae, Haleciidae and Syntheciidae. Transactions of the Royal Society of New Zealand 85: 301-356.

Ralph, P.M. (1966). Hydrozoa in Port Phillip Survey 1957-1963. Memoirs of the National Museum of Victoria 27: 157-166.

Ritchie, J. (1911). Hydrozoa (hydroid zoophytes and Stylasterina) of the "Thetis" expedition. Memoirs of the Australian Museum 4: 807-869.

Roberts, D. and Wells, F.E. (1980). The marine and estuarine molluscs of the Albany area of Western Australia. Records of the Western Australian Museum 8: 335-367.

Rosenzweig, P.A. (1984). A range extension for the European shore crab Carcinus maenas (Linn., 1758) in South Australia. South Australian Naturalist 59: 18-19.

Rudman, W.B. (2004). Further species of the opisthobranch genus Okenia (Nudibranchia: Goniodorididae) from the Indo-West Pacific. Zootaxa 695: $1-70$.

Ruiz Sebastian, C., Etheridge, S.M., Cook, P.A., O'Ryan, C. and Pitcher, G.C. (2005). Phylogenetic analysis of toxic Alexandrium (Dinophyceae) isolates from South Africa: implications for the global phylogeography of the Alexandrium tamarense species complex. Phycologia 44: 49-60.

Ryland, J.S. (1965). Catalogue of main marine fouling organisms (found on ships coming into European waters). Volume 2: Polyzoa. Organization for Economic Cooperation and Development, Paris. 83 pp.

Ryland, J.S. and Hayward, P.J. (1977). British anascan bryozoans. Cheilostomata: Anasca. Keys and notes for the identification of the species. Academic Press, London. 188 pp.

Sabbadin, A. and Graziani, G. (1967). New data on the inheritance of pigments and pigmentation patterns in the colonial ascidian Botryllus schlosseri. Rivista di Biologia 60: 559-98.

Schaffelke, B., Murphy, N. and Uthicke, S. (2002). Using genetic techniques to investigate the sources of the invasive alga Caulerpa taxifolia in three new locations in Australia. Marine Pollution Bulletin 44: 204-10.

Schrey, S.E., Carpenter, E.J. and Anderson, D.M. (1984). The abundance and distribution of the toxic dinoflagellate, Gonyaulax tamarensis, in Long Island estuaries. Estuaries 7(4B): 472-477.

Schuchert, P. (1996). The marine fauna of New Zealand: Athecate hydroids and their medusae (Cnidaria: Hydrozoa). New Zealand Oceanographic Institute Memoir 106: 1-159.

Shepherd, S.A. and Thomas, I.M. (eds) (1989). Marine invertebrates of southern Australia. Part II. South Australian Government Printing Division, Adelaide. $491 \mathrm{pp}$.

Skinner, S. and Womersley, H.B.S. (1983). New records (possibly introductions) of Striaria, Stictyosiphon and Arthrocladia (Phaeophyta) for southern Australia. Transactions of the Royal Society of South Australia 107: 59-68.

Slack-Smith, S.M. and Brearley, A. (1987). Musculista senhousia (Benson, 1842); a mussel recently introduced into the Swan River estuary, Western Australia (Mollusca: Mytilidae). Records of the Western Australian Museum 13: 225-230.

Smith, P.R. (1975). The estuarine ecology of two species of nassariid gastropods in South-Western Australia. MSc thesis, University of Western Australia.

Sorokin, Y.I., Sorokin, P.Y. and Ravagnan, G. (1996). On an extremely dense bloom of the dinoflagellate Alexandrium tamarense in lagoons of the Po River Delta: Impact on the environment. Journal of Sea Research 35: 251-255.

Southward, A.J. and Crisp, D.J. (1963). Barnacles of European Waters. In: Catalogue of Main Marine Fouling Organisms, Vol. 1, Barnacles. pp 1-46, figs 125. Organisation for Economic Cooperation and Development, Paris.

Sumner, C.E. (1972). Oysters and Tasmania. Tasmanian Fisheries Research 6: 1-15.

Sumner, C.E. (1974). Oysters and Tasmania. Tasmanian Fisheries Research 8: 1-12.

Sutherland, J.P. (1978). Functional roles of Schizoporella and Styela in the fouling community at Beaufort, North Carolina. Ecology 59: 257-264.

Taylor, R.W. (1983). Descriptive taxonomy: past, present, and future. In: Highley, E. and Taylor, R.W. (eds), Australian Systematic Entomology: A Bicentenary Perspective: 93-134. CSIRO, Melbourne.

Thomson, J.M. (1946). The fauna of the algal zone of the Swan River Estuary. A preliminary survey of Freshwater Bay with notes on the chief species. Journal of the Royal Society of Western Australia 30: $55-73$.

Thomson, J.M. (1952). The acclimatization and growth of the Pacific oyster (Gryphaea gigas) in Australia. Australian Journal of Marine and Freshwater Research 3: 64-73.

Thomson, J.M. (1954). The genera of oysters and Australian species. Australian Journal of Marine and Freshwater Research 5: 132-168.

Thomson, J.M. (1959). The naturalization of the Pacific 
oyster in Australia. Australian Journal of Marine and Freshwater Research 10: 144-149.

Turner, R.D. (1966). A Survey and Illustrated Catalogue of the Teredinidae (Mollusca: Bivalvia). The Museum of Comparative Zoology, Harvard University, Cambridge Massachusetts. 265 pp.

Turner, R.D. (1971a). Identification of marine woodboring molluscs. In: Jones, E.B.G. and Eltringham, S.K. (eds.), Marine Borers, Fungi and Fouling Organisms of Wood: 17-64. Organization for Economic Cooperation and Development, Paris.

Turner, R.D. (1971b). Australian shipworms. Australian Natural History. 17: 139-146.

Turpin, D.H., Dobell, P.E.R. and Taylor, F.J.R. (1978). Sexuality and cyst formation in pacific strains of the toxic dinoflagellate Gonyaulax tamarensis. Journal of Phycology 14: 235-238.

Utinomi, H. (1967). Comments on some new and already known cirripedes with emended taxa, with special reference to the parietal structure. Publications of the Seto Marine Biological Laboratory, Sirahama 15: 199237.

Vail, L.L. and Wass, R.E. (1981). Experimental studies on the settlement and growth of Bryozoa in the natural environment. Australian Journal of Marine and Freshwater Research 32: 639-656.

Van Name, W.G. (1945). The North and South American ascidians. Bulletin of the American Museum of Natural History 84: 1-476.

Verlaque, M., Brannock, P.M., Komatsu, T., VillalardBohnsack, M. and Marston, M. (2005). The genus Grateloupia C. Agardh (Halymeniaceae, Rhodophyta) in the Thau Lagoon (France, Mediterranean): a case study of marine plurispecific introductions. Phycologia 44: 477-496.

Verlaque, M., Durand, C., Huisman, J.M., Boudouresque, C.-F. and Le Parco, Y. (2003). On the identity and origin of the invasive Mediterranean Caulerpa racemosa (Caulerpales, Chlorophyta). European Journal of Phycology 38: 325-339.

Vigeland, I. (1971). Bryozoa. In: Black, J.H. (ed.), Port Phillip Survey 1957-1963. Victoria, Australia. Part 2. Memoirs of the National Museum of Victoria 32: 6582.

Walters, S. (1996). Ballast water, hull fouling and exotic marine organism introductions via ships - A Victorian study. Environment Protection Authority, Victoria Publication 494: 1-143.

Watson, J.E. (1973). Pearson Island Expedition 1969 - 9. Hydroids. Transactions of the Royal Society of South Australia 97: 153-200.

Watson, J.E. (1975). Hydroids of Bruny Island, southern Tasmania. Transactions of the Royal Society of South Australia 99: 157-176.

Watson, J.E. (1978). New species and new records of Australian athecate hydroids. Proceedings of the Royal Society of Victoria 90: 301-314.

Watson, J.E. (1980). The identity of two tubularian hydroids from Australia with a description and observations on the reproduction of Ralpharia magnifica gen. et sp. nov. Memoirs of the National Museum of Victoria 41: 53-63.
Watson, J.E. (1994). Shallow water hydroids from eastern Bass Strait. Victorian Naturalist 111: 65-73.

Watson, J.E. (1996). Distribution and biogeographic relationships of the hydroid fauna of the Australian west coast: A preliminary account. Scientia Marina 60: 75-83.

Watson, J.E. (1997). The hydroid fauna of the Houtman Abrolhos Islands, Western Australia. In: Wells, F.E. (ed.), The Marine Flora and Fauna of the Houtman Abrolhos Islands, Western Australia. Volume 2: 503546. Western Australian Museum, Perth.

Watson, J.E. (1999). Review of hydroids introduced to Victorian waters. In: Hewitt, C.L., Campbell, M.L., Thresher, R.E. and Martin, R.B. (eds), Marine biological invasions of Port Phillip Bay, Victoria. Centre for Research on Introduced Marine Pests. Technical Report No. 20: 88-109. CSIRO Marine Research, Hobart.

Watson, J.E. (2000). Hydroids (Hydrozoa: Leptothecatae) from the Beagle Gulf and Darwin Harbour, northern Australia. The Beagle 16: 1-82

Wells, F.E. (1984). A guide to the common molluscs of South-Western Australian estuaries. Western Australian Museum, Perth. 112 pp.

Wells, F.E. (1990). General introduction to the Albany area of Western Australia. In: Wells, F. E., Walker, D.I., Kirkman, H., and Lethbridge, R. (eds), The Marine Flora and Fauna of Albany, Western Australia: 1-5. Western Australian Museum, Perth.

Wells, F.E. and Bryce, C.W. (1986). Seashells of Western Australia. Western Australian Museum, Perth. 208 pp.

Wells, F.E. and Bryce, C.W. (1993). Seaslugs of Western Australia. Western Australian Museum, Perth. 184 pp.

Wells, F.E. and Huisman, J. (2004). Barrow Island Quarantine Marine Baseline Strategy. Report to ChevronTexaco Australia Pty Ltd, Western Australian Museum, Perth. 22 pp.

Wells, F.E. and Kilburn, R.N. (1986). Three temperate water species of South African gastropods recorded for the first time in southwestern Australia. Veliger 28: 453-456.

Wells, F.E., Longbottom, A.F. and Longbottom, J. (2005). The marine molluscs of Esperance Bay and the Recherche Archipelago, Western Australia. In: Wells, F.E., Walker, D.I., and Kendrick, G. The Marine Flora and Fauna of Esperance, Western Australia: 289-314. Western Australian Museum, Perth.

Wells, F.E. and Walker, D.I. (2003). Introduction to the Dampier marine environment. In: Wells, F.E., Walker, D.I. and Jones, D.S. (eds), Proceedings of the Eleventh International Marine Biological Workshop: The Marine Flora and Fauna of Dampier, Western Australia: 1-12. Western Australian Museum, Perth.

Western Australian Museum. (2001). Geraldton Port Survey. Identification of specimens. Report to the Geraldton Port Authority by the Department of Aquatic Zoology, Western Australian Museum.

Western Australian Museum. (2002). Esperance Port Survey. Identification of specimens. Report to the Geraldton Port Authority by the Department of Aquatic Zoology, Western Australian Museum. 
Western Australian Museum (2005). Barrow Island Survey for Introduced Marine Species. Western Australian Museum, Perth, ii +22 pp.

Willan, R.C. (1985a). Preliminary report on the arrival of a new mussel at Auckland, New Zealand. Poirieria, Auckland Museum Conchology Section 14: 2.

Willan, R.C. (1985b). Successful establishment of the Asian mussel Musculista senhousia (Benson in Cantor, 1842) in New Zealand. Records of the Auckland Institute and Museum 22: 85-96.

Willan, R.C. (1987a). The mussel Musculista senhousia in Australia: another aggressive alien highlights the need for quarantine at ports. Bulletin of Marine Science 4: 475-489.

Willan, R.C. (1987b). Phylogenetic systematics and zoogeography of Australian nudibranchs. 1. Presence of the aeolid Godiva quadricolor (Barnard) in Western Australia. Journal of the Malacological Journal of Australia 8: 71-85.

Willan, R.C. and Coleman, N. (1984). Nudibranchs of Australia. Australian Marine Photographic Index, Sydney. 56 pp.

Wilson, B.R. (1993/94). Australian Marine Shells Prosobranch Gastropods. Odyssey Publishing, Kallaroo, Western Australia. 2 volumes.

Wilson, B.R. (1998). Order Mytiloidea. In: Beesley, P.L., Ross, G.J.B., and Wells, A. (eds), Molluscs: The Southern Synthesis. Fauna of Australia. Volume 5: 250-253. CSTRO Publishing, Melbourne.

Wilson, B.R. and Kendrick, G.W. (1968). The recent appearance of Notospisula trigonella (Lamarck) (Mollusca: Bivalvia: Mactridae) in the Swan Estuary. Journal of the Malacological Society of Australia 1: 362-371.

Wilson, N. (2006). New record of the nudibranch Polycera hedgpethi Er. Marcus, 1964, in South Australia, with a discussion on its occurrence in Australia. Records of the Western Australian Museum, Supplement 69: 137-140.

Wilson, R.S. (1984). Neanthes (Polychaeta: Nereididae) from Victoria with descriptions of two species. Proceedings of the Royal Society of Victoria 96: 209226.

Wilson, R.S. (1988). Synonymy of the genus Nectoneanthes Imajima, 1972, with Neanthes Kinberg, 1866 (Polychaeta: Nereididae). Proceedings of the Biological Society of Washington 101: 4-10.
Wilson, R.S. (1999). Annelida: Polychaeta of Port Phillip Bay. In: Hewitt, C.L., Campbell, M.L., Thresher, R.E. and Martin, R.B. (eds), Marine biological invasions of Port Phillip Bay, Victoria. Centre for Research on Introduced Marine Pests Technical Report No. 20: 108-128. CSIRO Marine Research, Hobart, Tasmania, Australia.

Winston, J.E. (1982). Marine bryozoans (Ectoprocta) of the Indian River area, Florida. Bulletin of the American Museum of Natural History 173: 99-176.

Wirtz, P., Araújo, R. and Southward, A.J. (2006). Cirripedia of Madeira. Helgoland Marine Research 60: 207-212.

Wisely, B. (1958). The development and settling of a serpulid worm, Hydroides norvegica Gunnerus (Polycheata). Australian Journal of Marine and Freshwater Research 9: 351-361.

Womersley, H.B.S. (1984). The marine benthic flora of southern Australia. Part I. Government Printer, South Australia, Adelaide. 329 pp.

Womersley, H.B.S. (1987). The marine benthic flora of southern Australia. Part II. South Australian Government Printing Division, Adelaide. 481 pp.

Womersley, H.B.S. (2003). The marine benthic flora of southern Australia - Part IIID Ceramiales Delesseriaceae, Sarcomeniaceae, Rhodomelaceae. Australian Biological Resources Study'and State Herbarium of South Australia, Canberra and Adelaide. 533 pp.

Wyatt, A.S.J., Hewitt, C.L., Walker, D.I. and Ward, T.J. (2005). Marine introductions in the Shark Bay World Heritage Property, Western Australia: a preliminary assessment. Diversity and Distributions 11: 33-44.

Zeidler, W. (1978). Note on the occurrence of the European shore crab Carcinus maenas (Linn., 1758) in Australia. The South Australian Naturalist 53: 1112.

Zeidler, W. (1988). The European shore crab, Carcinus maenas in the Coorong-a potential threat to local fisheries. Transactions of the Royal Society of South Australia 112: 181-182.

Zibrowius, M. (1991). Ongoing modification of the Mediterranean marine fauna and flora by the establishment of exotic species. Mesogee 51: 83-107.

Manuscript accepted 18 February 2008. 